\title{
Türk Basınında Doğu-Batı Blokları Ekseninde 1981 Polonya Darbesi
}

\author{
Esra Türe* \\ (ORCID: 0000-0001-9875-0587) \\ Makale Gönderim Tarihi \\ 04.01.2021 \\ Makale Kabul Tarihi \\ 16.03.2021
}

\section{Atıf Bilgisi/Reference Information}

Chicago: Türe, E., "Türk Basınında Doğu-Batı Blokları Ekseninde 1981 Polonya Darbesi", Vakanüvis-Ulus/ararası Tarih Araştırmaları Dergisi, 6/1 (2021): 407-440.

APA: Türe, E. (2021). Türk Basınında Doğu-Batı Blokları Ekseninde 1981 Polonya Darbesi. Vakanüvis-Uluslararası Tarih Araştırmaları Dergisi, 6 (1) , 407-440.

\section{Öz}

Polonya'da meydana gelen Bağımsız Dayanışma Sendikası hareketi ve 13 Aralık 1981 tarihinde gerçekleştirilen darbe Doğu Avrupa başta olmak üzere tüm dünya için büyük önem taşımıştır. Polonya'da 13 Aralık 1981-22 Temmuz 1983 tarihleri arasında askeri yönetimin kontrolünde sıkıyönetim dönemi yaşanmıştır. Polonya'da yaşanan olaylar bir iç sorun gibi görülse de genel anlamda Doğu-Batı Bloku arasındaki ideolojik, siyasi ve ekonomik savaşı temsil etmiştir. Polonya'daki olaylar ve sıkıyönetim döneminde yaşanan gelişmeler tüm dünyada olduğu gibi Türk basını tarafından da yakından takip edilmiştir. Türk basınında Polonya konusuna yönelik gelişmeler hem aktarılmış hem de çok yönlü olarak değerlendirilmiştir. Çalışmamızda muhafazakâr bir yayın politikası izleyen Tercüman gazetesi, Atatürkçü niteliğini vurgulayan Cumhuriyet gazetesi ve iki gazeteye göre daha dengeli bir yayın politikası izlemeye çalışan Milliyet gazetesinden oluşan üç örneklem üzerinden basının Polonya olaylarına yaklaşımı ele alınmıştır.

Anahtar Kelimeler: Polonya, Dayanışma Sendikası, Komünizm, Sosyalizm, Doğu Avrupa.

*Dr., esrature.5520@gmail.com.

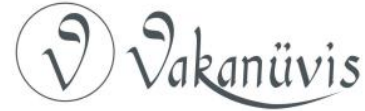




\section{Polish Coup On The Axis of East-West Blocks In The Turkish Press}

\section{Abstract}

The Independent Solidarity Unionmovement in Poland and the coup on December 13, 1981 were of great importance for the whole world, especially in Eastern Europe. A period of martiallaw was experienced in Poland between 13 December 1981 and 22 July 1983 under the control of the military administration. Even though the events in Poland are seen as an internal problem, they generally represented the ideological, political and economic war between the East-West Bloc. The events in Poland and the developments in theperiod of martiallaw have been closely followed by the Turkish press as well as all over the world. In the Turkish press, developments regarding the Polish issue have been conveyed and evaluated in a multifaceted way. In our study, the approach of the pres to Polish events was examined through three samples consisting of Tercüman newspaper following a conservative editorial policy, Cumhuriyet newspaper emphasizingits Kemalist character and Milliyet newspaper which tried to follow a more balanced editorial policy compared to two newspapers.

Keywords: Poland, Solidarity Union, Communism, Socialism, Eastern Europe.

\section{Giriş}

Polonya tarihinin başlangıcı 966 yılı olarak kabul edilmektedir. Polonya 16. yüzyılda varlığını Polonya-Litvanya Krallığı altında sürdürmüştür. 1772, 1793 ve 1795 yıllarında Rusya, Prusya ve Avusturya arasında bölüşülen Polonya 123 yıl Avrupa siyasi haritasından silinmiştir. ${ }^{1}$ Birinci Dünya Savaşı'nın başlamasıyla birlikte Polonyalı milliyetçiler de mücadele etmişler ve bağımsızlıklarını kazanmışladır. ${ }^{2} \mathrm{Bu}$ nedenle Polonya'nın modern devlet tarihinin başlangıcı 1918 yılı olarak kabul edilmektedir. ${ }^{3}$ Ancak Polonya ikinci Dünya Savaşı'nın başlarında 28 Eylül 1939 tarihinde yapılan anlaşma ile Almanya ve Sovyetler Birliği arasında paylaşılarak bir kere daha

\footnotetext{
${ }^{1}$ Magdalena Kubow, "The Solidarity Movement in Poland: Its History and Meaning in Collective Memory." The Polish Review, 58/2 (2013), p. 4.

2 Fahir Armaoğlu, 20. Yüzyıl Siyasi Tarihi (1914-1995), 23. Basım, İstanbul, 2017, s. 177.

3 Özgün Erler Bayır, Soğuk Savaş Sonrası Atlantikçilik-Avrupacılık ikileminde Polonya Dış Politikası, Basılmamış Doktora Tezi, İstanbul 2011, ss. 6, 7.
}

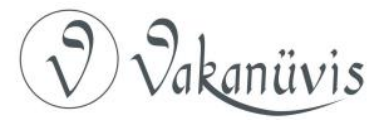


haritadan silinmiştir. İkinci Dünya Savaşı'ndan zaferle çıkacaklarını düşünen İngiltere, ABD ve Sovyetler Birliği 4-11 Şubat 1945 tarihleri arasında Yalta'da düzenledikleri konferans ile kendi çıkarları doğrultusunda barış düzenini oluşturmak istemişlerdir. Alınan kararlar arasında Polonya'nın varlığını yeniden tesis etmesini sağlayan "Ulusal Birlik Geçici Polonya Hükümeti" kurulması yer almıştır. ${ }^{4}$

İkinci Dünya Savaşı sona ermesine rağmen $A B D$, Sovyetler Birliği'ni tehdit unsuru olarak görmüş ve Batı Avrupa'yı korumak amacıyla Mart 1947'de Truman Doktrini'ni ${ }^{5}$, Eylül 1947'de ise Marshall Planı'nı uygulamaya sokmuştur. ${ }^{6}$ Sovyetler Birliği ikinci Dünya Savaşı'nda işgal ettiği Doğu Avrupa ülkelerinde komünist parti diktatörlükleri kurmuş ${ }^{7}$ ve Polonya, Romanya, Macaristan, Doğu Almanya, Arnavutluk ve Yugoslavya üzerinde etki sahibi olmuştur. 1947 yılında Avrupa'daki komünist partileri ile yaptığı toplantı sonucunda ise dünyanın iki bloka ayrıldığını açıklamıştır. ${ }^{8}$ iki blokun oluşması aynı zamanda Avrupa'nın "kapitalist" ve "komünist" şeklinde ikiye bölünmesi anlamına gelmiştir. ${ }^{9}$ Bu gelişmelerin ardından Sovyetler Birliği tehdidine karşı $A B D$ ve Batı Avrupa ülkeleri arasında 1949 yılında ortak savunma esasına dayanan sistem olarak NATO kurulmuştur. ${ }^{10}$ Sovyetler Birliği öncülüğündeki Doğu Bloku ülkeleri ise NATO'ya karşı 1955'te Varşova Paktı'nı kurmuşlardır. ${ }^{11}$

Polonya jeopolitik ve stratejik konumu itibariyle Sovyetler Birliği için büyük önem taşımıştır. Bu nedenle Sovyetler Birliği Polonya üzerinde sıkı bir denetim mekanizması kurmuş ve muhalif hareketlere izin

\footnotetext{
${ }^{4}$ Rifat Uçarol, Siyasi Tarih (1789-2014), 10. Basım, İstanbul, 2015, ss. 853, 854, 882, 883.

5 Mahmut Akkor, "II. Dünya Savaşı'nın Sonu ve Truman Doktrini'nin Ortaya Çıkışı", VAKANÜViS-Ulus/ararası Tarih Araştırmaları Dergisi, 2/2, (2017), s. 6.

6 Yusuf Çınar, "Modernleşme ve Bağımlılık Teorisi Ekseninde Marshall Yardımı ve Türkiye", MCBÜ Sosyal Bilimler Dergisi, 16/2, (2018), s. 331.

${ }^{7}$ William H. McNeill, Dünya Tarihi, Çev. Alaeddin Şenel, 6. Basım, Ankara, 2002, s. 802. ${ }^{8}$ Uçarol, a.g.e., ss. 937, 938.

${ }^{9}$ Oral Sander, Siyasi Tarih 1918-1994, 5. Basım, Ankara, 1996, s. 208.

10 Mehmet Gönlübol ve Haluk Ülman, "ikinci Dünya Savaşından Sonra Türk Dış Politikası (1945-1965): Genel Durum", Olaylarla Türk Dış Politikası (1919-1995), 9. Basım, Ankara, 1996, ss. 223, 224.

${ }^{11}$ Cem Karadeli, "Stalin ve Kruşçov Dönemlerinde Doğu Avrupa'da Sovyetler ve Krizler", Ufuk Üniversitesi Sosyal Bilimler Enstitüsü Dergisi, 8/15, (2019), s. 242.
}

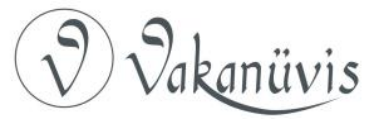


vermemiştir. ${ }^{12}$ Cumhuriyet gazetesi Polonyalı General Leon Dubucki'nin Federal Alman Der Spiegel dergisi ile yaptığı röportajdan önemli bir kesit paylaşmıştır. Dubicki'ye göre Sovyetler Birliği için önemli olan konu Polonya'nın askerî siyasi ve sosyal güvenliğiydi. Gazete, Polonya'nın Sovyetler Birliği için sahip olduğu stratejik önemi Fransız L. Express dergisinde yayınlanan uzman görüşlerini aktararak paylaşmıştır. Buna göre: Sovyetler Birliği'nden Demokratik Almanya'ya giden tüm haberleşme hatları Polonya'dan geçiyordu, yaklaşık 15 askeri petrol boru hattı Polonya'dan geçerek Doğu Almanya'ya ve Çekoslovakya'ya uzanıyordu. Doğu Almanya ve Çekoslovakya'daki Sovyet birliklerinin Sovyetler Birliği'ne giden güzergahı Polonya'dan geçiyordu. Varşova Paktı́nın ileri 220 hava üssünün 110'u Polonya'da yer alıyordu ve Varşova Paktı kuvvetleri Kuzey grubunun Sovyet komutanlığı da Polonya'da bulunuyordu ${ }^{13}$

Sovyetler Birliği kurduğu Doğu Bloku'nu koruma amacıyla tüm güç unsurlarını tehdit olarak kullanmıştır. Bu tehdit Doğu Avrupa'da reform hareketlerinin oluşumuna karşı caydırıcı bir unsur olmuştur. Ancak ekonomi sarsılmaya başladığında Doğu Avrupa'da iç muhalefet de büyümeye başlamıştır. ${ }^{14}$ Polonya Doğu Bloku ülkeleri arasında ekonomisi en kötü olan ülke olarak öne çıkmıştır. Komünist rejime karşı harekete geçmenin temelinde ekonomik sorunlar önemli yer tutmuştur. ${ }^{15}$

\section{Polonya Bağımsız Dayanışma Sendikası'nın Oluşumu}

Yalta Konferansı'ndan itibaren özgürlüğü elinden alınan Polonya' da ${ }^{16}$ ekonomik sorunlar çözülememiştir. 1979'da ekonomisi yüzde 2 küçülen Polonya, komünist siyasal sistem altında temel özgürlüklerinden de yoksun hale gelmiştir. ${ }^{17}$ Hükümetin 1980 yılının Temmuz ayında et fiyatlarına yaptığı zam sonucunda başlayan işçi

\footnotetext{
${ }^{12}$ Armaoğlu, a.g.e., s. 814.

13 "Polonya, Sovyet Avrupa Stratejisinde Kilit Ülke", Cumhuriyet, 10 Ocak 1982.

14"The Soviet Decision Not to Invade Poland, 1981" Blinders, Blunders, and Wars: What America and China Can Learn, by David C. Gompert et al., RAND Corporation, (2014), p. 140.

${ }^{15}$ Armaoğlu, a.g.e., s. 814.

${ }^{16}$ Kubow, a.g.m., p. 9

17"The Soviet Decision Not to Invade Poland, 1981" p. 140.
}

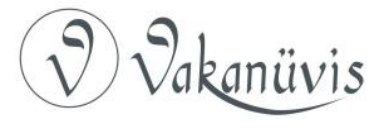


eylemleri, komünist bir ülkede komünist bir iktidar partisine tepki gösteren Polonya Dayanışma Sendikası'nın kurulmasını sağlamıştır. ${ }^{18}$ "Dayanışma"nın resmî bir hareket olarak doğuşu 7 Ağustos 1980 tarihinde gerçekleştirilen greve dayandırılmaktadır. Otuz yıllık usta vinç operatörü Anna Walentynowicz'in işten çıkarılması Polonya'da tepki yaratmıştır. İşsiz bir tersane elektrikçisi olan Lech Walesa ${ }^{19} 14$ Ağustos'ta Walentynowicz'in iş arkadaşlarına greve gitmeleri konusunda destek olmuştur. 17 Ağustos'ta "Dayanışma" bir hareket olarak resmî manifestosunu "Yirmi Bir Talep" şeklinde listelemiştir. ${ }^{20}$ Ekonomik sebeplerle harekete işçilerin hedefleri arasında siyasi talepler de yer almıştır. Bunlardan biri bağımsız sendikalar kurabilmekti. ${ }^{21}$ Yaşanan eylem ve grevler üzerine işçiler adına Walesa ile yönetim arasında müzakereler yapılmış ve 31 Ağustos 1980 tarihinde "Ağustos Anlaşmaları" imzalanmıştır. Bu anlaşmaya dayanarak 17 Eylül 1980 tarihinde Bağımsız ve Özerk Dayanışma Sendikası kurulmuş ve Sendika'nın başına Walesa getirilmiştir. ${ }^{22} 1981$ yılına gelindiğinde Sendika'nın üye sayısı 10 milyona yaklaşmıştır. ${ }^{23} 31$ Ağustos'ta imzalanan anlaşma o dönemde komünist bir ülkede eşi görülmemiş bir anlaşma olması, ${ }^{24}$ Sendika ise Doğu Bloku'nda kurulan

\footnotetext{
18 "Et Zammı ile Başlayan Çatışma 18 Ay Sürdü", Milliyet, 14 Aralık 1981.

1929 Eylül 1943 tarihinde dünyaya gelen Lech Walesa Küçük bir çiftçi ailenin çocuğudur. Walesa 1967 yılında Gdansk Tersanesi'nde gemi elektrikçisi olarak çalışmıştır. 1970 yılından sonra kendi departmanındaki sendikalar adına iş güvenliği sorumlusu olmuş, ancak yaptığı bir konuşmanın tepki çekmesi nedeniyle 1976 yılında işine son verilmiştir. Bunun ardından Walesa "muhalefet aktivisti" olarak ön plana çıkmıştır. Birkaç kez tutuklanan Walesa, 1980 yılında Gdansk Tersanesi'nde meydana gelen grevi yönetmiştir. 1980-1981 yılları arasında 16 ay süreyle "Dayanışma" Sendikası'nın başkanlığını yapmıştır. 13 Aralık 1981 tarihinde sıkıyönetimin ilan edilmesiyle birlikte hükümet tarafından gözetim altında tutulmuştur. Daha sonra serbest kalan Walesa 1983 yılında Nobel Barış Ödülü’nü almıştır. 9 Aralık 1990 tarihinde yapılan genel seçimlerde Polonya Cumhuriyeti Cumhurbaşkanı seçilmiş ve beş yıl bu görevde kalmıştır. Bkz. https://www.president.pl/en/president/polishpresidents/lech-walesa/, (17.03.2021).

${ }^{20}$ Kubow, a.g.m., p. 10.

21 J.M. Roberts, Avrupa Tarihi, Çev. Fethi Aytuna, İstanbul, 2015, s. 740.

${ }^{22}$ Abdulaziz Asyalı, Doğu Avrupa Ülkelerinin Sosyalizmden Kopuşu ve Demokratikleşme Süreci: Polonya Örneği, Basılmamış Yüksek Lisans Tezi, Mardin 2019, ss. 45, 46.

${ }^{23}$ Kubow, a.g.m., p. 12.

24 John J. Kulczycki, "The Beginnings Of The Solidarity Movement in Poznan, 19801981", The Polish Review, Vol. 27, No. 3/4 (1982), p. 154.
}

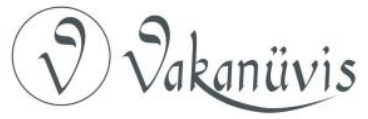


ilk bağımsız sendika olması nedeniyle önem taşımaktaydı ${ }^{25}$ Esasında komünizme karşı siyasi bir varlık olarak "Dayanışma" hareketi Ağustos 1980'de doğmuş olsa da temelinde 1956, 1968, 1970 ve 1976 yıllarındaki ayaklanma ve grevler de önemli etkiye sahip olmuştur. Zira belirttiğimiz bu yıllarda işçiler ekonomik sorunlar nedeniyle Komünist iktidara karşı seslerini duyurmaya başlamış ve ülkede demokrasi için de mücadelenin adımları atımıştı. ${ }^{26}$

Dayanışma Sendikası'nın oluşumunda önemli yer tutan isimlerden biri de Papa II. Jean Paul olmuştur. Polonya asıllı ve asıl ismi Karol Wojtyla olan Papa, ${ }^{27} 1978$ yılında bu göreve seçilmesiyle birlikte Jean Paul II ismini almıştır. Polonya halkının Katolik inancına sahip olması Vatikan ile manevi bağlarının güçlü olmasını sağlamıştır. ${ }^{28}$ Papa II. Jean Paul Polonya için nihai sembol ve umut veren kişi olarak görülmüştür. Papa'nın Haziran 1979'da Polonya'ya yaptığı ziyaret tarihi büyüklükte bir kalabalığa sahne olmuş ve Polonyalıları ulusal bağımsızlıklarını geri almaları için güçlendirmiştir. ${ }^{29}$ Sendika üzerinde Katolik Kilisesi'nin büyük etkisi olmuştur. ${ }^{30} \mathrm{ABD}$ Polonya'nın sahip olduğu stratejik önemi nedeniyle Dayanışma Sendikası'nı açıkça desteklemiştir. Sovyetler Birliği karşısında ABD'nin desteği "Dayanışma" için önemli bir güç kaynağı teşkil etmiştir. ${ }^{31}$ Sosyalist blok dönemindeki Polonya'da iş̧̧i sendikası Katolik kilisesi etkisi altındaydı.

\section{Darbenin Gerçekleştirilmesi ve Türk Basınında Değerlendirilmesi}

13 Aralık 1981 tarihinde Polonya Başbakanı olan Komünist Parti Genel Sekreteri ve Milli Savunma Bakanı Wojciech Jaruzelski başkanlığında Ulusal Kurtuluş Konseyi kurularak askerler yönetime el koymuştur. Jaruzelski aynı gün yaptığı konuşmada ülkede geçici olarak savaş durumu ve sıkıyönetim ilan edildiğini, tüm hakların ve özgürlüklerin askıya alındığını, yönetimin Ulusal Kurtuluş Konseyi'ne

\footnotetext{
25 “Dayanışma'nın 16 Aylık Mücadelesi”, Cumhuriyet, 14 Aralık 1981.

${ }^{26}$ Kubow, a.g.m., p. 5-9.

${ }^{27}$ Kubow, a.g.m., p. 9, 10.

${ }^{28}$ Asyalı, a.g.t., s. 46.

${ }^{29}$ Kubow, a.g.m., p. 9, 10.

${ }^{30}$ Yasin Aktay, "Türkiye'de İslam ve Sol veya İslamcılar ve Solcular", Modern Türkiye'de Siyasi Düşünce: Dönemler ve Zihniyetler, Ed. Tanıl Bora ve Murat Gültekingil, Cilt 9, İstanbul, 2009, s. 758.

${ }^{31}$ Armaoğlu, a.g.e., s. 815.
}

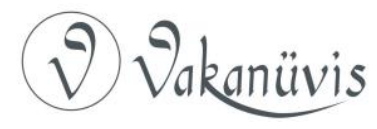


devredildiğini açıklamıştır. Jaruzelski'nin darbe gerekçelerinde sendikacıların yasalara uymadıkları, herkesi greve teşvik ettikleri ve yönetimi tehdit ettikleri yer almıştır. Bu durumun ülkeyi iç savaşa götüreceğini ileri süren Jaruzelski bunu önlemek amacıyla yönetime el koyduklarını savunmuştur. ${ }^{32}$ Dayanışma Sendikası'nın bütün binaları basılmış, iş̧̧i liderleriyle birlikte eski Komünist Parti Genel Sekreteri Gierek ile eski Başbakan Jaroszewicz de tutuklanmıştır. Ülkeye giriş ve çıkışlar yasaklanarak dış ülkelerle haberleşme kesilmiştir. Bunlar karşısında Dayanışma Sendikası halkı genel greve çağırmıştır. ${ }^{33}$ Walesa ise tutuklandıktan kısa bir süre serbest bırakılmıştır. ${ }^{34}$ Polonya Katolik kilisesi de halkın askeri yönetimin baskısı altında kaldığını ve bundan memnun olmadığını ifade ederek askeri yönetime karşı çıkmıştır. ${ }^{35}$ Kilise Polonya'daki cezaevlerinin, büyük askeri barakaların ve çadırların yetersiz kaldığını, tutuklanan binlerce işçi, aydın ve öğrencinin Wroclaw'daki "Nazi toplama kampına" yerleştirildiğini açıklamıştır. ${ }^{36}$ Askeri rejim ise Dayanışma Sendikası'ndan sonra kilise ve papazlara karşı da tavır alarak sindirmeye çalışmıştır. ${ }^{37}$

Polonya'da yaşanan darbe ve darbe sonrasında meydana gelen gelişmeler Türk basını tarafından yakından takip edilmiş ve değerlendirilmiştir. Milliyet gazetesi "Polonya'nın bağımsızlık sembolü ve Doğu Bloku işçilerinin 'onur lideri'” olarak gördüğü Lech Walesa'yı 1981 yılı için "dışta yılın adamı" olarak seçmiştir. ${ }^{38}$ Gazete yazarlarından Sami Kohen, Polonya'da ilan edilen sıkıyönetimi açıkça darbe olarak değerlendirmiştir. Jaruzelski'nin darbe gerekçesini yorumlayan Kohen, sosyalizm karşıtı güçleri bastırmak için sosyalist bir darbe yapıldığını ortaya koymuştur. ${ }^{39}$ Yine Milliyet gazetesi yazarlarından Metin Toker, komünist sistem tarihinde 1917 yılından beri yaşanan en önemli olayın Polonya'da gerçekleştiğine dikkat çekmiş ve Toker'e göre bu olay komünist yönetimin ülkeyi

\footnotetext{
32 "Polonya'da Yönetim Orduya Devredildi", Milliyet, 14 Aralık 1981.

33 "Polonya Sınırındaki Sovyet Birlikleri Alarmda", Tercüman, 14 Aralık 1981.

${ }^{34}$ Milliyet, 14 Aralık 1981.

35 "Genel Grev Olursa Rusya Müdahale Edecek", Milliyet, 18 Aralık 1981.

36 "Tutuklular Nazi Kampına Konuyor", Milliyet, 22 Aralık 1981.

37 "Tutuklular Nazi Kampına Konuyor", Milliyet, 22 Aralık 1981.

38 "Dışta Yılın Adamı", Milliyet, 31 Aralık 1981.

${ }^{39}$ Sami Kohen, "'Varşova'da Darbe", Milliyet, 14 Aralık 1981.
}

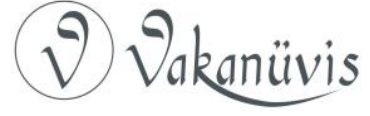


yönetemediğini, iktidarı başka bir güce bıraktığını kabul ettiği anlamı taşımıştır. ${ }^{40}$ Toker, komünist bir ülkenin komünist bir iktidar partisi olan Birleşik İşçi Partisi'nin ülkeyi yönetemediğinin içeride ve dışarıda anlaşılması üzerine Sovyetler Birliği'nin partinin iktidardan uzaklaştırılmasına göz yumduğunu belirtmiştir. ${ }^{41}$ Aynı gazete yazarlarından Mehmet Barlas'a göre Polonya'daki siyasi gelişmelerin ardında yatan asıl neden ekonomik sıkıntılardır. Enflasyon artmış, vatandaşlar yokluk çekmeye başlamıştır. ${ }^{42}$ Milliyet gazetesi muhabiri Orhan Duru ülkenin sağladığı kazançtan beklediği payı alamayan iş̧̧ilerin rejimden soğuduğunu belirtmiştir. Polonya'da halkın büyük çoğunluğunun ise Sovyet karşıtı ve anti-sosyalist olduğunu paylaşmıştır. ${ }^{43}$

Cumhuriyet gazetesi ise Polonya'da yaşanan olayların kökeninde ekonomik sebeplerle birlikte siyasal ve kültürel etkenlerin de varlığına dikkat çekmiştir. iktidara karşı bir direniş hareketi olarak değerlendirilen Dayanışma Sendikası, 35 milyonluk ülke nüfusunun 10 milyona yakın işçi kitlesini örgütlemiştir. Sendika "partiden bağımsız sendika" anlayışını, parti içindeki seçimlerin gizli oyla yapılmasını, basında farklı görüşlere yer verilmesini iktidara kabul ettirerek siyasal konumunu güçlendirmiştir. ${ }^{44}$ Aynı gazete yazarlarından Ergun Balcı Polonya'da yaşanan olayların bir iktidar mücadelesi ya da iktidarı paylaşma savaşı olduğunu ifade etmiştir. İşçiler, içerisinde "işçi" kelimesi geçen partinin iktidarına ortak olmak isterken parti, iktidar tekelinden vazgeçmek istememiştir. Balcı'ya göre ekonomik sorunlar bu kavgada sadece birbirlerini suçlamak için kullanılan bir argüman olmuştur. ${ }^{45}$

Yine Cumhuriyet gazetesi yazarlarından Uğur Mumcu gerçekleştirilen darbeyi şaşırtıcı bulmamış ve darbenin Sovyetler Birliği'nin isteği doğrultusunda gerçekleştirildiğini vurgulamıştır. Mumcu, Sovyetler Birliği'nden "ithal edilen" sosyalist rejimin

\footnotetext{
${ }^{40}$ Metin Toker, "Komünizm Tarihinde Bir Dönüm Noktası", Milliyet, 14 Aralık 1981.

${ }^{41}$ Metin Toker, "Polonya ve Finlandiya”, Milliyet, 20 Aralık 1981.

42 Mehmet Barlas, "Ordu Yönetimde", Milliyet, 14 Aralık 1981.

${ }^{43}$ Orhan Duru, "Polonya'da Halkın Büyük Çoğunluğu Sovyet Karşıtı Ve Anti-sosyalist", Milliyet, 25 Aralık 1981.

44 "Polonya Sorunu", Cumhuriyet, 15 Aralık 1981.

${ }^{45}$ Ergun Balcı, "Polonya: Bir Bunalımın Anatomisi”, Cumhuriyet, 22 Aralık 1981.
}

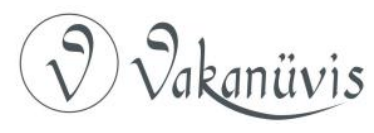


Polonya'da iflas ettiğini belirtmiştir. ${ }^{46}$ Ergun Balcı ise Sendika'nın sosyalizme karşı değil, sosyalizmin yanlış uygulanmasına karşı isyan ettiğini düşünmüştür. Zira işçiler sosyalist bir devlette hak ettikleri ağırlığı kazanmak istiyorlardı. Balcı, Sendika'nın verdiği "mücadeleyi" kazanması halinde fabrika, tersane gibi iş yerlerini özel girişimciye teslim etmesini mümkün görmemiştir. ${ }^{47}$

Tercüman gazetesi yazarı Nazlı llıcak'a göre de komünist sistemin kalesi olarak görülen madencilerin sıkı bir mücadele vermesi ülkede komünist sistemin çöktüğünün bir göstergesidir. ${ }^{48}$ Nazlı llıcak darbe olmasaydı Polonyalılar için iki seçenek öngörmüştür: Polonya'ya ya sükûn ve huzur ya da Sovyet tankları gelecekti. Her iki ihtimali de değerlendiren llıcak, sükûn ve huzurun sağlanması durumunda Polonyalıların yönetime katılma isteklerine, grev ve serbest seçimlere, basın ve yayın organlarında söz haklarına veda edeceklerini belirtmiştir. Sovyet tanklarının gelmesi durumunda ise çok kan akacă̆ını ifade ederek Polonyalıların yaşadığı durumu ortaya koymuştur. ${ }^{49}$

Ergun Balcı Polonya'da yaşanan olaylarda Dayanışma Sendikası'nın yaptığı yanlışlar üzerinde durmuş ve en büyük iki yanlışın Dayanışma Ulusal Konseyi'nin darbeden 2 gün önce 11 Aralık 1981'de Gdansk'ta ve 4 Aralık 1981'de Radom kentlerinde yaptığı toplantılar olduğunu savunmuştur. Gdansk'taki toplantıda siyasal rejimin niteliğinin belirlenmesi amacıyla halkoylaması çağrısı yapılmış, 1982 yılında yapılacak olan seçimlerin demokratik olması istenmiştir. Ayrıca parlamento hükümete olağanüstü yetki vermezse 17 Aralık'ta genel greve gidileceği ilan edilmiştir. Radom'daki toplantıda ise hükümet konuşmaları gizlice kaydetmiştir. Toplantıda iktidara nasıl geçileceği tartışılmış ve hükümet Walesa'nın "Çatışma artık kaçınılmaz olmuştur. Bu sistem savaşmadan değiştirilmez." ifadelerini koz olarak kullanmıştır. ABD'ye ait AP haber ajansında yer alan "Komünist Partinin genel seçimlerde, halk oylamasını kabul etmesi, kendi eli ile idam fermanını imzalaması demektir." Ifadesini aktaran Balcı, partinin

\footnotetext{
46 Uğur Mumcu, "Polonya Dersi..." Cumhuriyet, 15 Aralık 1981.

47 Ergun Balcı, "Kavram Kargaşası", Cumhuriyet, 29 Aralık 1981.

48 Nazlı llıcak, "Türkiye, Polonya, İtalya”, Tercüman, 03 Ocak 1982.

${ }^{49}$ Nazlı Ilıcak, "Batı-demokrasi ve sosyalizm”, Tercüman, 18 Aralık 1981.
}

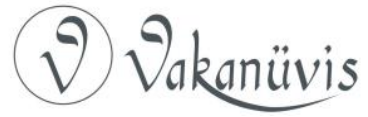


kendi idam fermanı yerine eline geçirdiği kozlar sayesinde Sendika'nın idam fermanını imzaladığını belirtmiştir. ${ }^{50}$

Darbenin hemen ertesi gününde Gdansk ve Varşova'da kurulan grev komiteleri işçileri direniş ve işgallere, halkı ise açlık grevine çağırmıştır. Bazı fabrikalarda 20 binden fazla işçi greve ve işgallere başlamıştır. Askeri yönetim ise bunlara karşı bir harekatta bulunmamış, ancak yeni önlemler almaya yönelmiştir. Başbakan General Jaruzelski başkanlığında kurulan ve general ile amirallerden oluşan Ulusal Savunma Komitesi'nden 20 yüksek rütbeli asker Walesa'yı Vaşova'ya getirerek grevleri önlemesini istemişlerdir. ${ }^{51} \mathrm{Kısa}$ sürede grev ve gösterilerin hızla büyümesi üzerine ${ }^{52}$ askerler bazı grev merkezlerine girerek grev ve direnişleri dağıtmaya başlamışlardır. ${ }^{53}$ Sendika ise dağıttığı binlerce bildiri aracılığıyla direnişten vazgeçmeyeceğini duyurmuştur. ${ }^{54}$

Darbe esnasında Polonya'da bulunan ve gelişmeleri aktaran Milliyet gazetesi muhabiri Orhan Duru, "Dayanışma”nın giderek güçlendiğini ve askerlerin oldukça sert davrandıklarını belirtmiştir. Duru'ya göre çok sayıda kişi yaşamını yitirdiği için olayların sonlanması kolay olmayacaktı. Duru ayrıca Polonya'da darbenin Ağustos ayından beri planladığı kanısının hâkim olduğunu ifade etmiştir. ${ }^{55}$ Görüşülmek üzere askeri yönetim tarafından Varşova'ya getirilen ve gözaltına alınan Walesa'dan o günden sonra haber alınamamıştır. Bu durum direnişlerin daha da artmasında önemli bir etken olmuştur. 20 Aralık 1981 tarihinde maden iş̧̧ileri bulundukları madenin bir girişini havaya uçurmuş ve 1300 işçi mahsur kalmıştır. Bölgeye giden askerlerin ise büyük bir kısmının işçilere katıldığı ve bazı bölgelerde de askerler ile polislerin çatıştığı bilgisi gelmiştir. Direnişçiler Walesa bırakılmadığı takdirde sabotajlarının süreceğini söylemişlerdir. ${ }^{56}$

\footnotetext{
50 Ergun Balcı, "Polonya: Bir Bunalımın Anatomisi", Cumhuriyet, 22 Aralık 1981.

51 “Polonya'da 20 Binden Fazla İşçi Greve Başladı", Milliyet, 15 Aralık 1981.

52 "Sovyetler Askeri Müdahaleye Hazırlanıyor", Tercüman, 16 Aralık 1981.

53 "Ordu, Grevdeki Fabrikalara Giriyor", Milliyet, 17 Aralık 1981.

54 “Direnişler Tankların Hücumu ile Kırıldı”, Tercüman, 18 Aralık 1981.

55 Orhan Duru, "Kan Döküldü Artık Olaylar Bitmez", Milliyet, 19 Aralık 1981.

56 “Havaya Uçurulan Ocakta 1300 İş̧i Mahsur Kaldı”, Tercüman, 21 Aralık 1981.
}

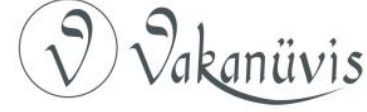


Darbenin üzerinden geçen 10 günde ülkede 200 kişi hayatını kaybetmiş ve yüzlerce kişi yaralanmıştır. İş̧i hareketlerini kontrol altına alamayan askerî yönetim direnişlere son verilmesi, sosyalist Polonya ve Varşova Paktı'nın tanınması, ekonomi ve huzurun birlikte sağlanması koşullarıyla sıkıyönetimin kaldırılacağını ve tutukluların serbest bırakılacağını duyurmuştur. Bu açıklama, General Jaruzelski'nin güç kaybettiğinin göstergesi olarak değerlendirilmiştir. ${ }^{57}$ Darbeden 13 gün sonra ise ilk defa halkın karşısına çıkan General Jaruzelski sıkıyönetimin "anarşiyi" sona erdirdiğini ve en kısa zamanda yönetimi sivil bir hükümete devredeceklerini beyan etmiştir. Jaruzelski ayrıca yeni bir yönetim programı hazırladıklarını ve bu programda daha önce işçiler lehine düzenlenen hakların korunacağını, sosyalist sistem içerisinde özerk bir iş̧̧i sendikasının yer alabileceğini belirtmiştir. ${ }^{58}$ Jaruzelski'nin bu açıklaması üzerine Nazlı llıcak ülkede anarşinin değil, geniş bir kitlenin verdiği hürriyet mücadelesinin hâkim olduğunu paylaşmıştır. ${ }^{59}$

Polonya'da darbe öncesi ve sonrası özgürlükler karşılaştırıldığında darbeden önce sınırlı da olsa özgürlüklerin olduğu kaydedilmiştir. Ülkede düşüncelerin açıkça ifade edilebildiği, hükümetin ve partinin eleştirilebildiği, sendikal örgütlenmelerin sağlanabildiği, sınırlı da olsa basın özgürlüğünün bulunduğu, eğlence aktivitelerinin mümkün olduğu bir yaşam mevcuttu. Darbeden sonra ise sendikalar ve insanların bir araya geldikleri mekanlar kapatılmış, özgürlükler sınırlandırılmış, çok sayıda insan tutuklanmış, basın özgürlüğü kısıtlanmış, halk askeri baskı altında suskun hale gelmiş, mağazaların önlerindeki kuyruklar daha da uzamıştır. ${ }^{60}$ Açlıkla karşı karşıya kalan askeri yönetim tüm dünyadan gıda yardımı istemiş ve kredi sağlanması için Batı ile temas başlatmıştır. ${ }^{61}$ Ekonomik bunalım yaşayan Polonya'da halkın temel gıda ve ihtiyaç gereksinimlerini karşılayamadıkları, çoğu maddelerin ise karneye bağlandığı aktarılmıştır. Bu manzarayı yerinde gören Orhan Duru rejim konusunun bir kenara bırakılarak Türk yönetiminden Polonya halkına

\footnotetext{
57 "General Jaruzelski Güç Durumda”, Milliyet, 23 Aralık 1981.

58 "Jaruzelski: 'En Kısa Zamanda Sivil Yönetime Dönülecek'”, Milliyet, 26 Aralık 1991.

59 Nazlı llıcak, "Türkiye, Polonya, İtalya”, Tercüman, 03 Ocak 1982.

60 Orhan Duru, "Darbeden Önce ve Sonra Polonya”, Milliyet, 20 Aralık 1981.

61 “Direnişler Tankların Hücumu ile Kırıldı”, Tercüman, 18 Aralık 1981.
}

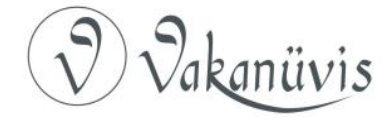


yardım edilmesini istemiştir. ${ }^{62}$ Mehmet Ali Birand da bu isteğe destek vermiştir. ${ }^{63}$ Kızılay Genel Müdür Yardımcısı ise yaptığı açıklamada Polonya askeri yönetimi ya da Kızılhaç'ı tarafından yardım talebi geldiği takdirde süratle yardım edeceklerini belirtmiştir. ${ }^{64}$ Artan sıkıntılar neticesinde General Jaruzelski sosyal, ekonomik ve siyasi reformlar gerçekleştirmek üzere Komünist partisinden üç yöneticiyi görevlendirmiştir. Yöneticilerin Komünist Partisi'nin kapatılarak yerine kilise ve sendikaları da kapsayan yeni bir partinin kurulmasını Askerî Konsey'e tavsiye ettikleri bildirilmiştir. ${ }^{65}$ Bu süreçte olumlu bir gelişme olarak 13 Aralık 1981 tarihinden itibaren Polonya'da ilk kez 4 Ocak 1982 tarihinde işçiler tüm sanayi kurumlarında işbaşı yapmışlardır. ${ }^{66} 1$ Mart 1982 tarihinde ise General Jaruzelski Moskova'ya giderek Sovyetler Birliği'nin yönetiminde yer alan Komünist Partisi Genel Sekreteri Leonid Brejnev ile görüşmüştür. Bu görüşmede Jaruzelski Polonya'nın sosyalizm yolundan ayrılmayacağını belirtirken ${ }^{67}$ Brejnev sosyalist blok içinde Polonya'daki gibi benzer olaylara izin verilmeyeceğini ve Polonya'ya her alanda yardım edeceklerini belirtmiştir. ${ }^{68}$

13 Aralık 1981'den itibaren uygulanmakta olan sokağa çıkma yasağı 2 Mayıs 1982 tarihinde kaldırılmıştır. ${ }^{69}$ Ancak askerî yönetim aleyhinde tekrar büyük gösterilerin yapılması üzerine 4 Mayıs'ta sokağa çıkma yasağı yeniden yürürlüğe konulmuştur. ${ }^{70} 13$ Aralık'tan Mayıs ayına kadar geçen sürede ülkedeki duruma bakıldığında siyasi ve ekonomik açıdan zor bir kış geçirilmiş, rejime muhalif olarak görülen binlerce kişi

62 Orhan Duru, "Polonyalının Ortalama Ücreti 20 Dolara Geliyor", Milliyet, 23 Aralık 1981.

${ }^{63}$ M. Ali Birand, "Türkiye, Polonya Halkına Hemen Yardım Etmeli", Milliyet, 25 Aralık 1981.

64 “Kızılay Çağrı Bekliyor”, Tercüman, 29 Aralık 1981.

65 "Polonya'da Reformlar İçin Komünist Partisi'nden Üç Yönetici Görevlendirildi", Tercüman, 01 Ocak 1982.

66 “Polonya'da Tüm Tesislerde İşçiler İşbaşı Yaptı”, Milliyet, 05 Ocak 1982.

67 "Jaruzelski: Polonya, Sosyalizmin Zayıf Bir Halkası Olmayacak", Cumhuriyet, 03 Mart 1982.

68 "Brejnev: 'Sosyalist Blokta Polonya Benzeri Olaylara Yer Verilmeyecek", Milliyet, 03 Mart 1982.

69 “Polonya'da Gece Sokağa Çıkma Yasağı Kaldırıldı”, Cumhuriyet, 03 Mayıs 1982.

70 "Varşova'da Tekrar Sokağa Çıkma Yasağı Konuldu”, Cumhuriyet, 05 Mayıs 1982.

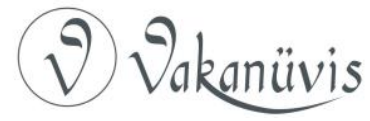


ve Walesa'nın da içinde bulunduğu Dayanışma Sendikası'nın ileri gelenleri tutuklanmış, iş̧̧ilere tanınan tüm haklar kaldırılmış, askerî yönetimin baskısı hâkim olmuş, ekonomi iyice bozulmuş ve yiyecek sıkıntısı baş göstermiş, dış borçlar ödenemez duruma gelmiştir. Askerî yönetim genel durumu yumuşatmak adına kısıtlamaları hafifletmeye başlamışken muhalifler 1 Mayıs 1982'de "Bahar Taarruzu" olarak adlandırılan eylemlerini yeniden başlatmışlardır. Bu hareketle birlikte Dayanışma Sendikası'nın halkı örgütleme noktasında hala etkin olduğu ve askerî yönetim tarafından sindirilemediği görülmüştür. Halkın da katıldığı gösterilerde Jaruzelski yönetimi eleştirilmiş, Walesa ile diğer tutukluların serbest bırakılması ve Dayanışma Sendikası'nın faaliyetlerine yeniden izin verilmesi istenmiştir. ${ }^{71}$ Ancak Sendika bununla yetinmeyip halkı genel greve çağırmış ${ }^{72}$ ve bu çağrısına karşılık bulmuştur. ${ }^{73}$

21 Temmuz 1982 tarihine gelindiğinde Jaruzelski yıl sonunda sivil yönetime geçilebileceğini duyurmuştur. ${ }^{74}$ Ancak darbenin üzerinden nerdeyse 9 ay geçmesine rağmen gösteriler ve tutuklamalar devam etmiştir. ${ }^{75}$ Polonya'da bunalımın artması üzerine Jaruzelski Brejnev ile görüşmek üzere Kırım'a gitmiştir. Jaruzelski görüşmede Polonya'daki bunalıma ABD'nin gizli bir şekilde desteklediği karşı devrimci yeraltı faaliyetlerinin neden olduğunu ileri sürmüştür. ${ }^{76}$ Dayanışma Sendikası'nın kuruluşunun ikinci yıldönümü olan 31 Ağustos 1982 tarihinde Polonya'da kanlı çatışmalar yaşanmıştır. ${ }^{77}$ Yaşanan olaylar gözlemciler tarafından "Dayanışma'nın başarısı" olarak nitelendirilmiştir. Sovyetler Birliği'ne göre olaylar "dışarıdaki yıkıcı merkezlerle işbirliği içinde olan serseriler" tarafından düzenlenmiştir. ${ }^{78}$ Fahir Armaoğlu da gösterilerde dış destek meselesine değinmiştir. Bir

\footnotetext{
71 Sami Kohen, "Bahar Taarruzu”, Milliyet, 05 Mayıs 1982.

72 “Polonya'da Dayanışma Radyosu Halkı Genel Greve Çağırdı, Tercüman, 11 Mayıs 1982.

73 “Polonya'da Dayanışma'nın Çağrısına Uyan Binlerce Kişi Gösteri Yaptı, Milliyet, 14 Mayıs 1982.

74 “Polonya'da 1227 Tutuklu Salıveriliyor", Milliyet, 22 Temmuz 1982.

75 “Dayanışma Önderliğinde Binlerce Gösterici Gdansk'ta Polisle Çatıştı”, Cumhuriyet, 14 Ağustos 1982.

76 "Jaruzelski: 'Polonya'daki Bunalıma ABD Neden Oldu'”, Milliyet, 17 Ağustos 1982.

77 “Polonya'da Çatışma: 3 Ölü Çok Sayıda Yaralı”, Tercüman, 02 Eylül 1982.

78 “Dayanışma'nın 2. Yıldönümü Gösterilerinde İki Kişi Öldü”, Milliyet, 02 Eylül 1982.
}

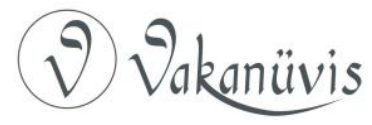


çelişkiye dikkat çeken Armaoğlu eski gösterilere oranla bu gösterilerde kişi sayısının daha az olduğunu, ancak daha çok kan döküldüğünü belirtmiştir. Göstericilerin bu şekilde gösterilerle rejimi yıkamayacaklarının farkında olduğunu vurgulayan Armaoğlu bu noktada dış faktörü göz önünde tutmak gerektiğini ifade etmiştir. Darbenin olduğu günlerde ABD ve Batı ülkeleri Dayanışma Sendikası'nı desteklemişlerdi. Armaoğlu son altı aydır özellikle Batı kanadından bu desteğin azaldığını, ancak son gösterilere bakıldığında göstericilerin hala ABD ve Batı'ya olan güveninin devam ettiğini ifade etmiştir. ${ }^{79}$

Polonya'da yumuşama adımları beklenirken parlamento, 8 Ekim 1982 tarihinde yaptığı toplantıda Dayanışma Sendikası dahil yüzden fazla bağımsız sendikayı fesheden yeni sendikalar yasasını kabul etmiştir. ${ }^{80}$ Doğu Bloku'nun ilk bağımsız sendikası olan 'Dayanışma'nın kapatılmasıyla özgür sendika dönemi sona ermiştir. ${ }^{81} A B D$, İngiltere ve Almanya'nın tepkisine neden olan yasa karşısında ABD Polonya'ya yaptırımlar uygulayacağını duyurmuştur. ${ }^{82}$ Vatikan'da Papa II. Jean Paul da Sendika'nın kapatılma kararını kınamıştır. ${ }^{83}$ Polonya'da karar protesto edilmiş ve binlerce işçi greve başlamıştır. ${ }^{84}$ Bu olaylardan bir ay sonra 10 Kasım 1982'de Brejnev ölmüş ${ }^{85}$ ve 12 Kasım 1982 tarihinde ${ }^{86}$ ise Walesa artık yönetimi tehdit eden bir unsur olarak görülmediği gerekçesiyle serbest bırakılmıştır. ${ }^{87}$ Walesa bu kararı şaşkınlık ve kuşkuyla karşıladığını ifade ederek ${ }^{88}$ "Dayanışma"nın eninde sonunda kazanacağını belirtmiştir. ${ }^{89}$

Walesa'nın serbest bırakılma kararında Ergun Balcı'ya göre Jaruzelski'nin kendini güçlü hissetmesi ve Walesa'nın serbest kalmasının tehlike yaratmayacağı kanısı etkili olmuştu. Balcı,

\footnotetext{
79 Fahir Armaoğlu, “Polonya'nın Dramı”, Tercüman, 03 Eylül 1982.

80 "Polonya'da Güç Dönem Başladı", Cumhuriyet, 10 Ekim 1982.

81 "Polonya Parlamentosu 'Dayanışma'yı Feshetti”, Milliyet, 09 Ekim 1982.

82 “Başkan Reagan: 'Polonya'ya Yaptırım Uygulanacak'”, Milliyet, 10 Ekim 1982.

83 “Papa, Dayanışma'nın Kapatılma Kararını Şiddetle Kınadı”, Milliyet, 11 Ekim 1982.

84 “Gdansk'ta Binlerce İşçi Greve Başladı", Cumhuriyet, 12 Ekim 1982.

85 "Brejnev Öldü", Tercüman, 12 Kasım 1982.

86 "Walesa Serbest Bırakıldı", Cumhuriyet, 13 Kasım 1982.

87 "Walesa Artık Yönetimi Tehdit Edici Bir Unsur Değil", Milliyet, 13 Kasım 1982.

88 "Walesa: 'Serbest Bırakılmamı Şaşkınlık ve Kuşkuyla Karşıladım'”, Milliyet, 16 Kasım 1982.

89 “Walesa: Anlaşmalıyız. Ama, Diz Çökerek Değil”, Cumhuriyet, 16 Kasım 1982.
}

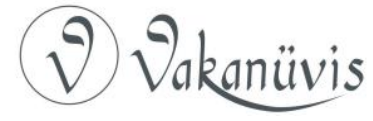


Jaruzelski'nin güçlenmesinde etkili olan iki husus üzerinde durmuştur. Birincisi Dayanışma Sendikası'nın 10 Kasım günü için yaptığı genel grev çağrısına işçilerin uymaması, ikincisi Jaruzelski'nin Polonya Katolik kilisesi ve Papa II. Jean Paul ile müttefik konumuna geçmiş olmasıydı. Ülkede çatışma istemeyen Polonya Başpiskoposu Josef Glemp Papa II. Jean Paul'un yanında yaptığı açıklamada 10 Kasım 1982 tarihi için yapılan genel greve gidilme çağrısına karşı çıkmıştı. Balcı'ya göre bu gelişmeler karşısında Dayanışma Sendikası'nın prestiji önemli bir darbe yemiştir. ${ }^{90}$ Bu süreçte Varşova'da Walesa ile görüşen Milliyet gazetesi muhabiri Turhan Aytul, kilise ile hükümetin komünist sistem içinde yeni bir Polonya konusunda çekiştiklerini, Walesa'nın ise bu "pazarlık"ta kullanılan "ulusal bir kahraman" olduğunu belirtmiştir. ${ }^{91}$

\section{Doğu ve Batı Blokları'nın “Siyasi Savaş” Alanı: Polonya}

Polonya'da yaşanan olayları ve darbeyi Doğu ve Batı Bloku ilişkilerinden bağımsız bir şekilde değerlendirmek eksik bir yaklaşım olarak kalmaktadır. Bu kısımda Sovyetler Birliği ve ABD'nin Polonya'daki askeri rejim sürecinde ortaya koyduğu politikalar ve bu politikaların Türk basınında nasıl değerlendirildiği ele alınmıştır.

Sovyetler Birliği resmî haber ajansı TASS'ın darbeye yönelik haberini aktaran Cumhuriyet gazetesinde, darbenin Polonya'daki anarşiye ve Dayanışma Sendikası liderlerinin ülkeyi ele geçirmeye yönelik eylemlerine karşı yapıldığı yer almıştır. ${ }^{92}$ Dayanışma Sendikası'nın hareketi Polonyalılara göre devrim, Sovyetler Birliği'ne göre karşı devrim olarak nitelendirilmiştir. ${ }^{93}$ Moskova radyosundan aktarılan haberde, yapılan baskın ile Dayanışma Sendikası'nın eylem planının ele geçirildiği belirtilmiştir. Eylem planında ülkede iç savaş çıkarılacağı, ancak bu planı içeren belgelerin ele geçirilmesiyle iç savaşın önlendiği iddia edilmiştir. ${ }^{94}$ Sovyetler Birliği Komünist Partisi, İtalyan Komünist

\footnotetext{
${ }^{90}$ Ergun Balcı, “Polonya'da Ne Oldu?", Cumhuriyet, 23 Kasım 1982.

91 "Walesa Düşünceli Ama Kararlı...", Milliyet, 26 Kasım 1982.

92 "TASS: Harekatın Hedefi Polonya'yı Ele Geçirmeye Çalışanlar", Cumhuriyet, 14 Aralık 1981.

93 Orhan Duru, “' 'Dayanışma' Hareketi Sovyetler'e göre 'Karşı Devrim', Polonyalılara Göre 'Devrim'”, Milliyet, 21 Aralık 1981.

94 “Moskova Radyosu: 'Dayanışma'nın 3 Aşamalı Eylem Planı Ele Geçirildi'”, Milliyet, 18 Aralık 1981.
}

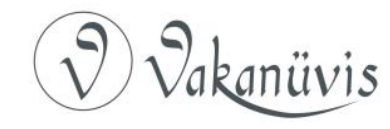


Partisi'ne yazdığı mektupta Polonya'da ABD desteğinde gerçekleşecek bir darbenin önüne geçilmesi için sıkıyönetim ilan edildiğini savunmuştur. İdiaya göre sıkıyönetim ilan edilmeseydi Aralık ayı sonunda $A B D$ destekli düzen karşıtları iktidarı ele geçirecekti. ${ }^{95}$ Doğu Bloku yaşanan olayların Polonya'nın iç işi olduğunu belirtmekle birlikte darbeyi olumlu karşılamıştır. ${ }^{96}$

Batı Bloku’na baktığımızda ABD Savunma Bakanı Caspar Weinberger, Polonya'daki durumun tehlikeli olduğunu ve "filizlenen özgürlüğün yeniden çiğnenip geçilebileceğinden" korku duyduklarını belirtmiştir. ${ }^{97}$ Polonya'daki darbe ve sendikal hakların durdurulması tüm dünyanın dikkatini çekmiş, ancak özellikle Batılı sendika ve iş̧̧i kuruluşları darbeye sert tepkiler göstermişlerdir. ABD Başkanı Ronald Wilson Reagan, Polonya'ya karşı doğrudan bir müdahalede bulunmaması için Sovyetler Birliği'ni açıkça uyarmıştır. ${ }^{98}$ Reagan Polonya'daki sıkıyönetim ilanının Sovyet desteği ile gerçekleştirildiğini vurgulamış ve askerî yönetim devam ettiği sürece Polonya'ya ekonomik yardım yapılmayacağını açıklamıştır. ${ }^{99}$ ABD'nin Polonya' daki darbeden Sovyetler Birliği'ni sorumlu tuttuğunu açıkça söylemesi üzerine TASS'da yayınlanan yazıda ABD'nin Polonya'da silahlı bir ayaklanma başlatmak için talimat verdiği aktarılmıştır. ${ }^{100}$

Darbenin üzerinden bir hafta geçmeden yabancı basın ve Türk basınında Polonya ordusu darbe yapmasaydı Sovyetler Birliği'nin müdahalede bulunabileceği açıkça yer almaya başlamıştır. Varşova Paktı Genel Komutanı Sovyet Mareşali Viktor Kulikov'un 10 Aralık 1981 tarihinde Varşova'ya gelerek General Jaruzelski'ye “Eğer siz müdahale yapmazsanız, Polonya'ya biz müdahale ederiz" şeklinde ültimatom verdiği aktarılmıştır. ${ }^{101}$ Milliyet gazetesi yazarlarından Mehmet Barlas, Polonya'da Sovyetler Birliği'nin askerî bir müdahalede

\footnotetext{
95 “Polonya'da Sıkıyönetim, ABD Desteğindeki Bir Darbeyi Önlemek İçin İlan Edildi”, Tercüman, 18 Mart 1982.

96 “Doğu Ne Diyor?", Cumhuriyet, 15 Aralık 1981.

97 "Haig: Varşova, Reformlar İçin Bize Güvence Verdi", Cumhuriyet, 14 Aralık 1981.

98 "Reagen, Moskova'yı 'Herhangi Bir Eyleme Geçmemesi' İçin Uyardı”, Milliyet, 15 Aralık 1981.

99 "ABD Başkanı: Askeri Yönetime Yardım Yok", Cumhuriyet, 19 Aralık 1981.

100 "TASS: ABD İsyan Talimatı Verdi", Cumhuriyet, 20 Aralık 1981.

101 "Genel Grev Olursa Rusya Müdahale Edecek", Milliyet, 18 Aralık 1981.
}

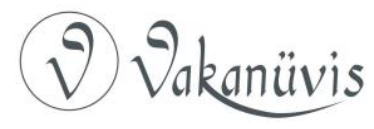


bulunmasındansa yönetimin Polonya ordusuna geçmesini daha olumlu karşılamıştır. ${ }^{102}$ Sovyet yetkililerin açıklaması referans gösterilerek aktarılan haberde Jaruzelski muhalif hareketleri bastıramadığı takdirde Sovyetler Birliği'nin askerî yardımda bulunacağı bildirilmiştir. ABD ise Sovyetler Birliği'ni uyararak ticari ambargo koyabileceğini, Polonya'ya da ekonomik yaptırımlar uygulayabileceğini duyurmuştur. Ancak Sovyetler Birliği ABD'den gelen bu açıklamaları Polonya'nın iç işlerine

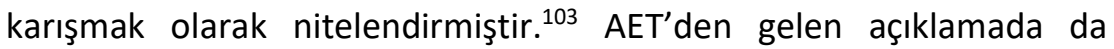
Sovyetler Birliği'nin müdahalesi halinde Polonya'ya yapılan ekonomik yardımların durdurulacağı bildirilmiştir. ${ }^{104}$ Batı'nın ve NATO'nun Polonya'daki gelişmelere yaklaşımını gözlemleyen Milliyet gazetesi yazarı Mehmet Ali Birand ekonomik yaptırım uyarılarının yapıldığını, ancak Sovyetler Birliği'ni müdahaleye itecek davranışlardan da kaçınıldığını belirtmiştir. ${ }^{105}$

$A B D$ uyarılarının ardından olası bir Sovyetler Birliği müdahalesine karşı tüm Doğu Bloku ülkelerine ambargo uygulama kararı almıştır. ${ }^{106}$ Reagan'ın Brejnev'e Polonya'daki baskı rejiminin sonlanmaması halinde misillemeler yapacaklarını belirten bir uyarı mektubu gönderdiği, ancak Brejnev'in bu mektuba olumsuz cevap verdiği bildirilmiştir. ${ }^{107}$ Bunun ardından ABD Polonya'daki gelişmelerin sorumlusu olarak gördüğü Sovyetler Birliği'ne de ekonomik yaptırım kararı almıştır. ABD ve Sovyetler Birliği arasında yaşanan Polonya gerginliği Doğu-Batı ilişkilerini yeniden kopma noktasına getirmiştir. ${ }^{108}$ ABD Sovyetler Birliği'ne karşı aldığı yaptırım kararlarını açıklamadan önce Türkiye dahil olmak üzere tüm müttefiklerine bildirmiştir. ABD müttefiklerinden aynı yaptırımları uygulamasını beklemese de manevi destek beklentisi taşımıştır. Türkiye bu konuya yönelik olarak ABD'ye cevap vermemiştir. Ancak Türk yetkililer Polonya'daki olaylara

\footnotetext{
102 Mehmet Barlas, “Ordu Yönetimde”, Milliyet, 14 Aralık 1981.

103 "Moskova, Jaruzelski Yönetimine Desteğini Resmen Açıkladı", Cumhuriyet, 16 Aralık 1981.

104 "AET: Sovyetler Müdahale Ederse, Polonya'ya Yardım Durur", Cumhuriyet, 16 Aralık 1981.

105 “Polonya Dünü Bazı Grevler Dışında Olaysız Geçirdi”, Cumhuriyet, 15 Aralık 1981.

106 "Ordu, Grevdeki Fabrikalara Giriyor", Milliyet, 17 Aralık 1981.

107 "Reagan: Brejnev Mektubuma Olumsuz Yanıt Verdi", Cumhuriyet, 29 Aralık 1981.

108 "ABD, Sovyetler'e Ambargo Uygulayacak", Milliyet, 31 Aralık 1981.
}

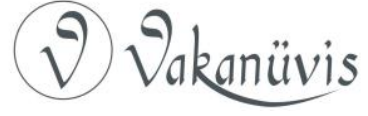


dışarıdan müdahalede bulunulmaması, halkın kendi yönetim biçimini belirleyebilmesi ve Helsinki Nihai Senedi'ndeki ${ }^{109}$ maddelerin ihlal edilmemesi şeklinde siyasal dileklerde bulunmuşlardır. Ayrıca Sovyetler Birliği'ne karşı ekonomik ambargo uygulamanın sadece Türkiye ekonomisine zarar vereceği gerçeğini de açıkça ifade etmişlerdir. ${ }^{110}$ Türk Dışişleri Bakanı Iilter Türkmen darbe konusunda değerlendirmede bulunarak Polonyalıların kendi rejimlerini seçme hürriyetine sahip olmadıklarını belirtmiştir. Türkmen yaşanan olayların parlamenter demokrasiyi tesis etmek amacına değil, rejimin yumuşatılması amacına yönelik olduğunu, ancak dışarıdan bir müdahale ile bunun durdurulduğunu ifade etmiştir. ${ }^{111}$ Ancak Türkmen dış müdahaleye ilişkin olarak Sovyetler Birliği'nin adını açıkça anmaktan kaçınmıştır. ${ }^{112}$

Türkiye bu noktada Polonya'daki sorunların Polonyalılar tarafından çözülmesi gerektiği görüşünü savunmakla birlikte $A B D$ 'nin duyduğu kaygıları taşımıştır. ${ }^{113}$ Türkiye'nin yanı sıra 4 Ocak 1982 tarihinde Brüksel'de toplanan AET dışişleri bakanları sıkıyönetime son verilmesi çağrısında bulunarak Polonya ve Sovyetler Birliği'ne karşı ekonomik ambargo uygulamayacaklarını bildirmişlerdir. ${ }^{114}$ Reagan ise Batı Avrupa'ya baskı uygulayarak Polonya olaylarının sorumlusu olarak Sovyetler Birliği'nin görülmesini ve $A B D$ gibi ekonomik yaptırımların uygulanmasını istemiştir. Batı Avrupa ise olayları Polonya'nın iç sorunu olarak görmeyi tercih etmiş ve Sovyetler Birliği'ni tahrik ederek olayların Doğu-Batı ilişkilerini zedeleme boyutuna ulaşmasına engel

109 Helsinki Nihai Senedi, 1973 yılında başlatılan ve 1975 yılında tamamlanan Avrupa Güvenlik ve İşbirliği Konferansı sonucunda 33 Avrupa ülkesi ile ABD ve Kanada'nın imzalandığı belgedir. Helsinki Nihai Senedi, Ikinci Dünya Savaşı'ndan sonra Avrupa'da kurulan statükonun siyasi yönden kabul edilmesi ve Doğu-Batı ilişkilerinde yumuşamanın insani yönünün geliştirilmesi gerektiğinin kabul edilmesi esaslarına dayanmaktadır. Bkz. Jale Civelek, "Helsinki Son Senedi, Paris Şartı ve AGiT", Marmara Üniversitesi Avrupa Topluluğu Enstitüsü Avrupa Araştırmaları Dergisi, 14/1 (2006), ss. 3-5.

110 "NATO, Polonya İçin Olağanüstü Toplanıyor", Milliyet, 05 Ocak 1982.

111 "Türkmen: Türkiye Polonya'ya Benzetilemez", Milliyet, 07 Ocak 1982.

112 "Türkmen: Türkiye, Polonya'ya Yardım Yapılmasına Taraftar", Cumhuriyet, 10 Ocak 1982.

113 “Ankara: 'Polonya Kendi Sorunlarını Kendisi Çözmeli'”, Cumhuriyet, 14 Aralık 1981.

114 "AET Bakanlar Konseyi Polonya'da Sıkıyönetime Son Verilmesi Çağrısında Bulundu", Cumhuriyet, 05 Ocak 1982.

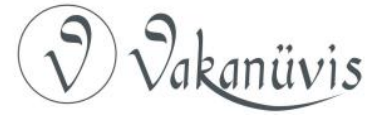


olmak istemiştir. Zira oluşacak bir krizden ABD’nin değil, olayın merkezinde olan Avrupa'nın etkileneceği aşikârdır. ${ }^{115}$

AET dışişleri bakanlarından sonra 11 Ocak 1982 tarihinde NATO Dışişleri Bakanları Polonya'daki olayları görüşmek üzere Brüksel'de olağanüstü toplanmıştır. $A B D$ bu toplantıda Sovyetler Birliği'nin Polonya'daki olaylardan sorumlu tutulmasını ve sert bir şekilde eleştirilmesini istemiştir. ABD'nin istediği gibi NATO Polonya'da sıkıyönetim ilan edilmesini, insan haklarının çiğnenmesini ve temel hürriyetlerin "yok edilmesini" eleştirmiştir. Ancak ekonomik yaptırımlarla ilgili karar Sovyetler Birliği'nin askeri müdahalesi söz konusu olduğu takdirde görüşülmek üzere ertelenmiştir. ${ }^{116}$ NATO toplantısının ardından Sovyetler Birliği ve Polonya da ortak bildiri yayınlayarak ABD'yi kınamıştır. ${ }^{117}$ Reagan için ekonomik ambargo kararında destek görmesi önemliydi. Çünkü ABD Avrupalı müttefikleri tarafından desteklenmediği sürece Sovyetler Birliği'ne uyguladığı ambargonun etkisiz kalacağının farkındaydı. ${ }^{118}$

Cumhuriyet gazetesi yazarlarından Ali Sirmen ABD'nin Sovyetler Birliği'ne uyguladığı ekonomik ambargoda Polonya'yı bahane olarak kullandığını savunmuştur. Sirmen ABD'nin soğuk savaş ortamını geri getirmek ve Sovyetler Birliği ile ilişkilerini soğuk tutmak istediğini belirtmiştir. Zira Batı Almanya da dahil NATO'nun askeri kanadında yer alan Avrupa ülkeleri Avrupa'da nükleer silahların sınırlandırıması konusunda ABD ile Sovyetler Birliği arasında diyalogun başlaması şartını öne sürmekteydi. Sirmen'e göre Reagan bu diyalogdan kaçmak için Polonya olaylarını bahane ederek soğuk savaş ortamını geri getirmek vebu ortam içerisinde Sovyetler Birliği ile yapılacak görüşmelerin sonuç vermeyeceğini ileri sürme fırsatı elde etmek

\footnotetext{
115 Mehmet Ali Birand, "Polonya Toz Bulutu Arasında, Türkiye'nin Demokrasi Takvimi”, Milliyet, 08 Ocak 1982.

116 “Polonya'da Durum Normale Dönmezse NATO Sovyet'lere Ekonomik Müeyyide Uygulayacak", Tercüman, 12 Ocak 1982.

117 "Sovyet-Polonya Ortak Bildirisinde ABD Kınandı", Cumhuriyet, 14 Ocak 1982.

118 "Reagan: 'Batılıların Desteği Olmazsa Sovyetler'e Ambargo Etkisiz Kalır', Milliyet, 19 Ocak 1982.
}

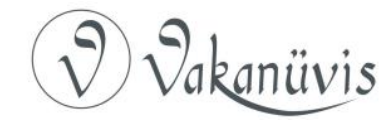


istemiştir. Ancak Batı'nın Avrupa kanadı bu ambargo uygulamasına destek vermemiştir. ${ }^{119}$

Milliyet gazetesi yazarı Çetin Altan da bu konuya vurgu yaparak $A B D$ ve Avrupa basınında Doğu ve Batı Blokları arasında asıl meselenin Polonya değil, Batı Almanya olduğunun yazılmaya başlandığını aktarmıştır. ABD'nin buğday dışında bir alışverişinin olmadığı Sovyetler Birliği'ne rahatlıkla uyguladığı ekonomik ambargoyu Avrupa'nın da uygulamasını istemesi önemli sorunlar doğurmaktaydı. Zira Avrupa ülkelerinin Sovyetler Birliği olan alışverişleri ekonomilerinde önemli bir yer tutmaktaydı. ABD bu süreçte Batı Avrupa'ya yerleştirilecek orta menzilli füzelerin üretimine başlamış ve Batı Almanya'yı Sovyetler Birliği'ne karşı baskıyı artırması için zorlamaya başlamıştı. Batı Almanya ise iki blok arasında dengeyi korumaya çalışarak $A B D^{\prime}$ nin bu isteklerini uygulamaktan kaçınmaya çalışmaktaydı. Çetin Altan Polonya olaylarının iki blok arasındaki dengeleri değiştirecek bir nitelikte görülmediğini belirterek bloklar arasındaki asıl çatışmanın Batı Almanya üzerinde yaşanacağına dikkat çekmiştir. ${ }^{120}$

1982 yılında ABD Başkanı Reagan, 30 Ocak gününü dünyada "Polonya Halkı ile Dayanışma Günü" ilan ederek Polonya'daki işçi hareketlerine olan desteğini bir kez daha göstermiştir. Ayrıca Reagan bu çerçevede "Polonya Polonyalılarındır" isimli televizyon programı hazırlatarak bütün Batı ve Batı yanlısı ülkelerde yayınlamıştır. Buna karşı misilleme yapan Sovyetler Birliği ise Doğu Bloku ülkelerinde "Kim Kimdir?" isimli programla Polonya'daki ABD casusluk hareketlerini gösteren bir film yayınlamıştır. Milliyet gazetesi bu durumu 1950'li yılların "soğuk savaşı"na benzeterek "televizyonla propaganda savaşı" yapıldığına dikkat çekmiştir. ${ }^{121}$ Başbakan Bülend Ulusu da "Polonya Polonyalılarındır" programına katılarak ${ }^{122}$ bir anlamda Türkiye'nin tarafını göstermiştir. Reagan'ın "Polonya halkının davası bizim davamızdı" sözünü aktaran Ergun Balcı Reagan'ın aynı dayanışmayı neden Şili, El Salvador, Guatemala ve Güney Afrika halklarıyla

\footnotetext{
${ }^{119}$ Ali Sirmen, "Polonya Bahane", Cumhuriyet, 03 Ocak 1982.

120 Çetin Altan, “Dikkatler Batı Almanya'ya da Kayıyor”, Milliyet, 17 Ocak 1982.

121 "Milyonlarca İnsan ABD ve Sovyetler'in TV ile Propaganda Savaşını İzledi", Milliyet, 02 Şubat 1982.

${ }^{122}$ Ali Sirmen, “Polonya'ya Bakmak”, Cumhuriyet, 04 Şubat 1982.
}

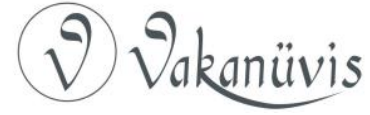


kurmadığını eleştirmiştir. ${ }^{123}$ Ali Sirmen ise Reagan'ın Polonya halkına olan desteğini "Reagan Show" şeklinde nitelendirmiştir. ${ }^{124} A B D$ 'nin ve Sovyetler Birliği'nin Polonya'ya karşı yaklaşımlarını değerlendiren Uğur Mumcu, ABD'nin Polonya'daki askeri yönetime tepki gösteren ve iş̧̧ileri savunan sözlerini samimi bulmamıştır. Mumcu da ABD destekli Şili darbesini örnek göstererek darbe sonrasında ezilen işçi sınıfını hatırlatmıştır. Bu noktada insan hakları savunuculuğu açısından değerlendirildiğinde ABD’nin Şili'deki askerî yönetimi desteklerken Polonya'daki askerî yönetime karşı olmasını inandırıcı bulmamıştır. Aynı şekilde Şili'deki askerî yönetime karşı olan Sovyetler Birliği'nin Polonya'daki askerî yönetimi desteklemesini de eleştirmiştir. ${ }^{125}$

Polonya olaylarına farklı yaklaşarak basında "deney" kavramına vurgu yapan yazarlar olmuştur. Mehmet Barlas Polonya'da yaşanan olayları "ilgi çekici bir deney" olarak değerlendirmiştir. Doğu Bloku içerisinde Sovyet müdahalesinin görüldüğü ülkeler Macaristan ve Çekoslovakya olmuştu. Bu ülkelerdeki sorun komünist parti içerisindeki kavgaların dışarıya yansımasıydı. Barlas'a göre bu ülkelerden farklı olarak Polonya'da iktidar, merkezi parti ve Sendika şeklinde iki yapıya yükselmiştir. Barlas parti Sovyetler Birliği müdahalesini desteklese dahi Sendika'nın buna karşı çıkacağını ve kanlı direnişlerin başlayacağını belirtmiştir. Ancak yazar, Jaruzelski'nin bu iki merkez karşısında Sovyetler Birliği-parti-ordu üçlüsünü birleştirme dengesini Doğu Bloku içerisindeki "ilgi çekici bir deney" olarak görmüştür. ${ }^{126}$ Cumhuriyet gazetesi yazarı Yalçın Doğan ise Polonya'nın "tarihte yeni bir deneyin" başlatılması için seçilmiş bir yer olduğunu ifade etmiştir. Doğan Polonya'da 1970 'lerden itibaren oluşturulmaya çalışılan ve sosyalist sistemin yapısına ters olan tüketim toplumu yaratma düşüncesine dikkat çekmiştir. ${ }^{127}$

${ }^{123}$ Ergun Balcı'nın vurguladığı Şili, El Salvador, Guatemala ve Güney Afrika bölgeleri binlerce insanın öldüğü ve buna rağmen $A B D^{\prime}$ nin halkı değil yönetimleri desteklediği bölgelerdir. Bkz. Ergun Balcı, "Polonya Halkı ile Dayanışma Günü", Cumhuriyet, 02 Şubat 1982.

${ }^{124}$ Ali Sirmen, "Polonya'ya Bakmak", Cumhuriyet, 04 Şubat 1982.

125 Uğur Mumcu, "Şili'den Polonya'ya...", Cumhuriyet, 20 Aralık 1981.

126 Mehmet Barlas, "ilgi Çekici Bir Deney", Milliyet, 17 Aralık 1981.

127 Yalçın Doğan, “Neden Polonya?", Cumhuriyet, 22 Aralık 1981.

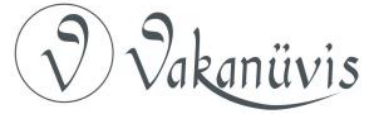


Uğur Mumcu Polonya'daki olayları daha geniş bir perspektiften ele alarak Avrupa komünizmi ile Sovyet Marksizmi bağlamında değerlendirmiştir. İki ideoloji arasındaki en büyük sorunun "proletarya diktatörlüğü" konusunda çıktığını belirten Mumcu Sovyet Marksizminin "proletarya diktatörlüğünü" kapitalizmden sosyalizme geçerken zorunlu bir aşama olarak gördüğünü, Avrupa komünizminin ise burjuva devlet yapısı ve kurumları içerisinde işçi ve emekçilere de örgütlenme imkânıverdiğini vurgulamıştır. Avrupa komünizminin revizyonizmin mirasçısı olduğunu ifade Mumcu Avrupa komünizmi ile Sovyet Marksizmi arasında yüzyıllık bir savaşın var olduğuna dikkat çekmiştir. Mumcu bu savaş göz önünde bulundurulduğunda Avrupalı komünistlerin Polonya olayları için "Marksist-Leninist sistemin çöküşü" değerlendirmelerinin daha iyi anlaşllabileceğini göstermiştir. ${ }^{128}$ Ergun Balcı Doğu Avrupa'da sosyalist ülkelerde yaşanan sıkıntıların Sovyetler Birliği'nde neden yaşanmadığına dikkat çekmiştir. Sovyetler Birliği'nin kurulmasında rol oynayan isimlerden biri olan Lev Troçki'nin "Sosyalizmin süngü ile kurulabileceğine inanlar, ayaklarına taş bağlayıp, kendilerini denize atsınlar" sözünü aktaran Balcı, Doğu Avrupa'da sosyalizm Sovyet ordusu ile kurulduğu ve öz malları olmadığı için sıkıntıların yaşandığını vurgulamıştır. ${ }^{129}$

Sovyetler Birliği'nin Polonya'ya askerî bir müdahalede bulunma olasılığını değerlendiren Mehmet Barlas bunun savaşa yol açmayacağını ifade etmiştir. Çünkü Polonya Doğu Bloku üyesidir. Olası bir müdahalenin Doğu-Batı ilişkilerinde sadece sertleşmeye neden olacağını belirtmiştir. ${ }^{130}$ Uğur Mumcu'ya göre de Polonya meselesi ABD ve Sovyetler Birliği arasında siyasi ve ideolojik bir savaş boyutundadır. ${ }^{131}$ Ergun Balcı Polonya konusuna farklı bir açıdan bakmış ve Vaşova Paktı'ndan yani Doğu Bloku'ndan ayrılan bir Polonya'nın $A B D$, Sovyetler Birliği ve Batı ülkeleri için ne denli büyük bir sorun olacağına dikkat çekmiştir. Balcı'ya göre Polonya'nın Varşova Paktı'ndan çıkması Pakt'ın dağılmasıyla sonuçlanabilirdi ve bu durum Sovyetler Birliği kadar ABD'yi de olumsuz etkileyebilirdi. Zira NATO da dağılabilir ve $A B D$ 'nin Batı Avrupa üzerindeki ekonomik ve siyasi

\footnotetext{
128 Uğur Mumcu, “ideolojik Açıdan...”, Cumhuriyet, 02 Ocak 1982.

129 Ergun Balcı, "Kavram Kargaşası", Cumhuriyet, 29 Aralık 1981.

130 Mehmet Barlas, “Akıl, Tek Yoldur!..”, Milliyet, 15 Aralık 1981.

131 Uğur Mumcu, “Kiminle Dayanışma?”, Cumhuriyet, 03 Şubat 1982.
}

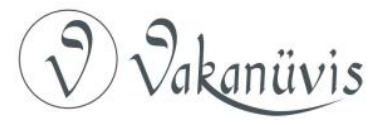


hegemonyası son bulabilirdi. Doğu ve Batı Almanya birleşerek Avrupa'nın merkezinde büyük bir güç haline gelebilirdi ve bu da diğer Avrupa ülkelerini ürkütebilirdi. Bu nedenle Batı Avrupa ülkeleri de Polonya'nın Varşova Paktı́ndan ayrılmasını istemezdi. Bu ihtimalleri sıralayan Balcı, ABD'nin Dayanışma Sendikası'na verdiği desteğin sadece Sovyetler Birliğini huzursuz etme amacı taşıdığını, daha ileriye gitmeyeceğini düşünmüştür. ${ }^{132}$

\section{Yumuşama Dönemi ve Sıkıyönetimin Kaldırılması}

1982 yılının Aralık ayı, sıkıyönetimin kaldırılmasının beklendiği bir aydı. Bu nedenle Dayanışma Sendikası liderleri Aralık ayı için aldıkları grev kararlarını iptal etmişlerdir. ${ }^{133}$ Bir süredir tutuklu kişilerin de serbest bırakılmasıyla cezaevlerindeki tutuklu sayısı 700'e düşmüştür. Ancak Polonya'da görülen yumuşa adımlarının Brejnev'in ölümünden sonraya rastlamasının gözlemcilerin dikkatini çektiği aktarılmıştır. ${ }^{134}$ Jaruzelski 12 Aralık 1982'de yaptığı konuşmada temel kısıtlamaların yıl sonuna kadar yürürlükten kaldırılacağını, yakın bir gelecekte de tüm yasakların kaldırılacağını açıklamıştır. ${ }^{135} 16$ Aralık'ta ise Walesa'nın bir konuşma yapması bekleniyordu, ancak konuşma metni Batılı gazetecilere önceden dağıtılmıştı. Metinde yeni bağımsız sendikaların kurulması için çalışacaklarını ve zafere ulaşacaklarını içeren ifadelerin yer alması ${ }^{136}$ nedeniyle askerî yönetim Walesa'yı gözaltına alarak yapacağı konuşmayı engellemiştir. ${ }^{137}$

Askerî yönetimin üzerinde durduğu konulardan biri Walesa'nın prestijinin ve önderlik gücünün etkinliğinin hangi boyutta olduğunu tespit etmek olmuştur. Bu süreçte iktidar sözcüleri sürekli olarak "Dayanışma" diye bir hareket kalmadığını ve Walesa'nın sıradan bir vatandaş olduğunu tekrarlamıştır. ${ }^{138} 1982$ yılının sonu itibariyle Polonya'da sıkıyönetimin askıya alınmasını öngören yasa parlamento

\footnotetext{
132 Ergun Balcı, "Polonya ve Bölünmüş Avrupa”, Cumhuriyet, 09 Şubat 1982.

133 "Dayanışma Sendikası Aralık Ayı İçin Planlanan Tüm Grevleri İptal Etti", Milliyet, 28 Kasım 1982.

134 "Polonya'da 237 Tutuklu Daha Salıverildi", Cumhuriyet, 01 Aralık 1982.

135 "Polonya'da Sıkıyönetim Askıya Alınıyor", Milliyet, 13 Aralık 1982.

136 "Lech Walesa: Zafer Bizim Olacak", Cumhuriyet, 16 Aralık 1982.

137 "Polonya'da Askeri Yönetim, Walesa'yı Gözaltına Alarak Susturdu", Milliyet, 17 Aralık 1982.

138 Nilüfer Yalçın, “Şimdi 'Walesa Efsanesi' Tartışılıyor”, Milliyet, 17 Aralık 1982.
}

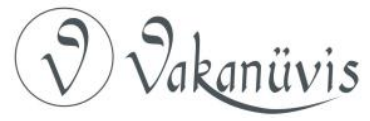


tarafından kabul edilmiştir. Ancak diğer yandan yasa Jaruzelski yönetimine geniş yetkiler tanıyarak muhalefete karşı daha sert önlemler almanın da önünü açmıştır. International Herald Tribuno gazetesinin yasaya ilişkin değerlendirmesini aktaran Cumhuriyet gazetesi "General Jaruzelski bir eli ile verdiğini, öteki eli ile fazlasıyla alıyor" ifadesini paylaşmıştır. ${ }^{139}$

Dayanışma Sendikası'nın güçlenmesinde etkin olan Papa II. Jean Paul yumuşama döneminde de etkin olmuştur. Belirtilmelidir ki Polonya kimliği için Katoliklik vazgeçilmez bir unsur olarak görülmüştür. ${ }^{140}$ ikinci Dünya Savaşı sonrasında Polonya Katolik kilisesi ahlaki otoriteye sahip tek kurum olarak varlığını korumuş ve kilise yandaşlarının sayısı azalmamıştır. ${ }^{141}$ Vatikan darbe öncesinde olduğu gibi darbe sonrasında da "Dayanışma"nın yanında olmuştur. Papa II. Jean Paul 1 Ocak 1981'de Vatikan'da düzenlediği ayinde Dayanışma Sendikası'nın "adalet ve barış" örgütü olduğunu ve Sendika'yı desteklerini belirtmiştir. ${ }^{142}$ Polonya'daki durumu yakından takip eden Papa Haziran 1983 yılı için Polonyagezisi programı yapmıştır. Ancak Papa II. Jean Paul bu ziyaret tarihine kadar tüm siyasi tutukluların serbest bırakılmasını istemiştir. ${ }^{143}$ Polonya hükümeti ise bu isteği reddetmiştir. ${ }^{144}$

Sıkıyönetimin askıya alınmasından sonra Polonya'da 1983 yılının 1 Mayıs'ı nasıl geçeceği de dünya kamuoyu tarafından merakla takip edilmiştir. 1 Mayıs gösterilerinde on binlerce kişi askerî yönetim aleyhinde sloganlar atarken Jaruzelski resmî kutlamaları başlattığı başka bir meydanda ülkede sosyal istikrar devam ederse birkaç ay sonra sıkıyönetimin tamamen kaldırılabileceğini duyurmuştur.

139 "Polonya'da Sıkıyönetim Askıya Alınırken, Baskı Daha da Arttı", Cumhuriyet, 20 Aralık 1982.

${ }^{140}$ Foti Benlisoy, "Türk Milliyetçiliğinde Katedilmemiş Bir Yol: 'Hıristiyan Türkler'", Modern Türkiye'de Siyasi Düşünce: Milliyetçilik, Ed. Tanıl Bora ve Murat Gültekingil, Cilt 4, 3. Basım, İstanbul, 2008, s. 932.

${ }^{141}$ Marcin Zaremba, "The 'War Syndrome': World War II and Polish Society." Seeking Peace in the Wake of War: Europe, 1943-1947, edited by Stefan-Ludwig Hoffmann et al., Amsterdam University Press, Amsterdam, 2015, p. 36.

142 "Dayanışma'nın Çağrısı”, Milliyet, 02 Ocak 1982.

143 “Polonya'da En Uzun Gün”, Cumhuriyet, 01 Mayıs 1983.

144 "Polonya Hükümeti Siyasi Tutukluları Salmayı Reddetti", Cumhuriyet, 04 Mayıs 1983.

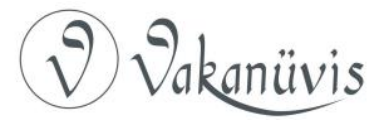


Kapatılan Dayanışma Sendikası'nın yer altı liderleri ise yönetimi protesto etmek için işçilere çağrıda bulunmuştu. Jaruzelski resmî kutlamalar dışında gösteri yapılmamasını, aksi takdirde Papa II. Jean Paul'un Haziran ayında yapacağı ziyaretin tehlikeye gireceğini belirtmiştir. Sıkı güvenlik önlemleri altında gerçekleştirilen gösterilerin son bir yıldır yapılan en büyük gösteri olduğu aktarılmıştır. ${ }^{145}$

Polonya hükümetinin açıklamasına göre resmî gösterilere altı milyona yakın kişi katılmıştır. Jaruzelski yönetim aleyhindeki gösterileri "fiyasko" şeklinde değerlendirirken Walesa gösterileri başarılı bulmuş ve beklentileri de aştığını belirtmiştir. ${ }^{146}$ Jaruzelski 1 Mayıs öncesinde Papa II. Jean Paul'un Haziran ayında yapacağı ziyaret üzerinde özellikle durmuş ve ziyareti tehlikeye düşürecek olayların yaşanmaması için halkı sık sık uyarmıştır. Ergun Balcı Polonya halkının dinlerine ne kadar bağlı olduğunu hatırlatarak Jaruzelski'nin bu uyarısının dahi gösterileri durdurmadığına dikkat çekmiştir. Balcı'ya göre ortaya çıkan tablo askerî yönetime karşı duyulan tepkinin göstergesiydi. ${ }^{147}$ Walesa bu süreçte yitirdikleri hakları geri alma konusunda oldukça kararlıydı. ${ }^{148}$

Papa II. Jean Paul 16 Haziran 1983 tarihinde Polonya gezisine başlamıştır. Papa'nın gelmesi hem kapatılan Dayanışma Sendikası'nın yer altı liderleri hem de Polonya hükümeti açısından önemli beklentiler taşımaktaydı. Hükümet bu ziyaretle ülkenin "istikrara kavuştuğunu" tüm dünyaya kanıtlamayı planlarken Sendika'nın yer altı örgütleri Vatikan'ın "Dayanışma"yı desteklediğini belirtmesini beklemiştir. Papa'nın gezisi Vatikan ve Polonya hükümeti tarafından "barış ve sevgi ziyareti" olarak nitelendirilse de siyasi açıdan ehemmiyet taşımaktaydı. Papa'nın geldiği gün Walesa da Papa'yla görüşeceğini söylemiştir. Ancak Walesa'nın askeri yönetim tarafından göz hapsine alınması gezi sırasındaki ilk siyasal sorun olarak değerlendirilmiştir. ${ }^{149}$ Polonya kökenli Papa II. Jean Paul açısından ise bu geziyle Batı'nın Polonya

145 “Polonya'da Olağanüstü Önleme Rağmen On binlerce Kişi Hükümeti Protesto Etti”, Cumhuriyet, 02 Mayıs 1983.

146 “Polonya'da Gösteri Bitti, Tartışma Başladı", Cumhuriyet, 03 Mayıs 1983.

${ }^{147}$ Ergun Balcı, "Polonya'da Durum", Cumhuriyet, 05 Mayıs 1983.

148 "Walesa: 'Ancak Tüm Haklarımızı Geri Aldığımız Zaman Susacağım'”, Milliyet, 16 Haziran 1983.

149 “Papa II. Jean Paul Polonya'da Lech Walesa Göz Hapsinde", Cumhuriyet, 17 Haziran 1983.

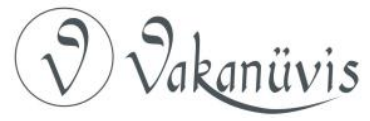


kilisesini ve “Dayanışma”yı desteklediğini göstermek istediği belirtilmiştir. ${ }^{150}$

Hükümet aylardır ülkede gösteri ve protestolara engel olmak için ciddi önlemler almıştı. Özellikle Papa'nın geliş tarihi yaklaştıkça bu önlemler daha da artmıştı. Ancak hükümetin korktuğu olmuş ve Papa'nın gezisinin ilk gününde 50 bin kişi toplanmıştır. St. John Katedralinde konuşan Papa II. Jean Paul komünist rejimi eleştirirken göstericiler de "Papa bizimle, yaşasın Walesa" diye bağırmış ve sıkıyönetimin kalkmasını istemişlerdir. ${ }^{151}$ Papa'nın daha sonra Varşova Stadyumu'nda düzenlenen ayinine 90 bin kişinin,, ${ }^{152}$ açık hava toplantısına ise 1 milyon kişinin katıldığı aktarılmıştır. ${ }^{153}$ Papa, kapatılan Dayanışma Sendikası'nın "karargahı" olarak görülen Katoviçe'de yaklaşık 2 milyon kişi karşısında yaptığı konuşmada Sendika'yı desteklediğini söylemiş ve hükümeti Sendika üyeleri ile diyalog kurmaya çağırmıştır. ${ }^{154}$ Daha önceki aylarda Dayanışma Sendikası tarafından yapılan grev çağrılarına beklenen ilgi gösterilmezken Papa'nın ziyaretinde sayıları milyonlara ulaşan kalabalığın toplanması "Vatikan'ın siyasi başarısı" olarak değerlendirilmiştir. Askerî yönetimin gösterilere müdahalede bulunmaması ve Walesa'nın Papa ile görüşmesine izin vermesi ise "yumuşa" sağlamaya çalıştıklarının göstergesi olarak yorumlanmıştır. ${ }^{155}$ Ancak Papa'nın ilk dört günde bu kadar kalabalık kitleleri toplaması ve halk arasında taşkınlıkların yaşanması bir yandan askerî yönetimi tedirgin etmiştir. Askeri yönetim Papa ve Katolik kilisesinin sözlerinde durmadığını belirterek Papa'nın gezinin dini yönleri ile ilgilenmesini istemiştir. ${ }^{156}$ Papa II. Jean Paul 23 Haziran günü

\footnotetext{
150 Ali Sirmen, “Papa Polonya'da”, Cumhuriyet, 18 Haziran 1983.

151 “Papa, Polonya'yı Karıştırdı”, Tercüman, 18 Haziran 1983.

152 "Jean Paul'un Varşova Stadı́ndaki Ayinine 90 Bin Kişi Katıldı", Milliyet, 19 Haziran 1983.

153 "Walesa-Papa Görüşmesi Bugün”, Cumhuriyet, 19 Haziran 1983.

154 “Papa 'Dayanışma Sendikası'nı Desteklediğini Açıkladı”, Cumhuriyet, 21 Haziran 1983.

155 “Papa-Walesa Görüşmesi Bekleniyor”, Tercüman, 20 Haziran 1983.

156 “Papa, Poznan'da II Kez Dayanışma Sendikası'nın Adını Kullandı”, Milliyet, 21 Haziran 1983.
}

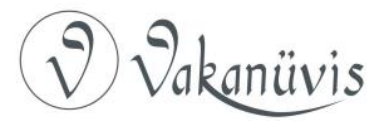


Walesa görüşmüş ve aynı gün gezisini tamamlayarak Vatikan'a dönmüştür. Görüşme hakkında ise bilgi verilmemiştir. ${ }^{157}$

Papa'nın gezisine ilişkin gözlemlerini aktaran Ergun Balcı gezinin daha ilk gününden itibaren Jaruzelski'nin hoşuna gitmeyecek şekilde gelişmeye başladığını ifade etmiştir. Zira Papa konuşmalarında din konusunda bir sözcük kullanırken özgürlük ve işçi hakları konusunda on sözcük kullanmıştır. Balcı'ya göre Jaruzelski Papa'nın gezisinden umduğunu bulamamıştır. ${ }^{158}$ Geziyi halkın gözüyle değerlendiren Nazlı llıcak ise Papa'nın gelmesiyle halkın hürriyet havasını soluduğunu gözlemlemiş ve Papa'nın halkın gözünde adeta haçlı seferinin komutanı gibi görüldüğü benzetmesini yapmıştır. ${ }^{159}$ Uğur Mumcu, Papa'nın bu gezisiyle Vatikan'ın Polonya'da dinsel konulardan ziyade siyasal olaylara önem verdiğinin anlaşıldığına vurgu yapmıştır. Mumcu Polonya'da Papa II. Jean Paul'un rejim karşıtlarının gerçek lideri, Walesa'nın ise şimdilik Papa'nın Polonya'daki temsilcisi olduğunu belirtmiştir. Mumcu, Papa II. Jean Paul'un bu göreve gelme sebebinin Polonya olayları olduğuna dikkat çekmiştir. ABD, Polonya'da Moskova güdümünde olan yönetimin son bulmasını istemekteydi. Vatikan Polonya'daki olaylarda ağırlığını Dayanışma Sendikası'ndan yana koymuştur. Bunu ABD'nin baştan beri planladığı stratejisini uygulamaya koyduğu aşamalardan biri olarak gören Mumcu, Polonya'nın ABD ve Sovyetler Birliği arasında "siyasal bir savaş alanı" haline geldiğini söylemiştir. ${ }^{160}$

Papa'nın ziyaretinin ardından Polonya Birleşik İşci Partisi 4 Temmuz 1983 tarihinde Gdansk'ta bir toplantı düzenlemiş ve toplantıya Jaruzelski de katılarak konuşma yapmıştır. Jaruzelski1980 yılında Polonya hükümeti ile işçiler arasında Gdansk'ta imzalanan ve Bağımsız Dayanışma Sendikası'nın oluşumuna imkân veren Gdansk anlaşmasının ruhuna sadık kaldıklarını beyan etmiştir. Jaruzelski ayrıca Komünist

157 “Walesa İle Görüşen Papa Vatikan'a Döndü”, Milliyet, 24 Haziran 1983.

158 Ergun Balcı, “Papa'nın Polonya Gezisi”, Cumhuriyet, 23 Haziran 1983.

159 Nazlı llıcak, "Yürü Hür Maviliğin Gittiği Son Hadde Kadar...", Tercüman, 01 Temmuz 1983.

160 Uğur Mumcu, “Papa Eylemde...”, Cumhuriyet, 28 Haziran 1983.

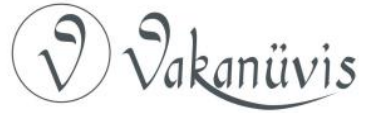


Parti'nin halkın desteğini kaybettiğini de kabul etmiş ve işçilerin güveninin tekrar kazanılması gerektiğine vurgu yapmıştır. ${ }^{161}$

Temmuz ayı ile birlikte sıkıyönetimin kaldırılma konusu Polonya'nın en önemli gündemi olmuştur. 22 Temmuz 1983'te kaldırılması öngörülen sıkıyönetim öncesinde askeri yönetim toplumu denetim altında tutabilmek amacıyla sert ve ağır hükümler içeren bir yasa tasarısı hazırlamıştır. Tasarının son 3 yılda kazanılan hakları kısıtladığı aktarılmıştır. Geçilmesi planlanan yeni dönem Milliyet gazetesinde "sıkı yasa dönemi" olarak adlandırımıştır. Walesa tasarıya sert tepki göstererek bunun yerine sıkıyönetimi tercih edeceğini söylemiştir. ${ }^{162}$ Parlamento 21 Temmuz 1983 tarihinde yaptığı toplantıda Devlet Konseyi'ne sıkıyönetimi kaldırma ve olağanüstü hal ilan etme yetkisi vermiştir. ${ }^{163} 22$ Temmuz'da ise Jaruzelski sıkıyönetimi kaldırmış, ancak yönetim karşıtı hareketlerin yeni yasalarla sıkıyönetimden daha sert bir şekilde cezalandırılacağını açıklamıştır. ${ }^{164}$ Cumhuriyet gazetesi bu yeni dönem için kullanılan "sıkıyönetimsiz bir sıkıyönetim" ifadesini aktarmıştır. ${ }^{165}$ Batılı gözlemcilerin değerlendirmeleri aktarılan Tercüman gazetesinde ise sıkıyönetimin kaldırılmasının "göstermelik" olduğu yer almıştır. ${ }^{166}$ Reagan sıkıyönetimin "gerçek anlamda" kalkması gerektiğini vurgulamıştır. Sovyetler Birliği basını ise Polonya'daki sorunların "Batı emperyalizminden" kaynaklandığını belirterek sorunların hala çözülemediğini, ${ }^{167}$ rejim karşıtı hareketlere karşı devletin sert davranacağını vurgulamıştır. ${ }^{168}$

Sıkıyönetimin kaldırımasının ardından siyasal tutuklular serbest bırakılmaya başlanmıştır. Ancak muhalefet liderleri ile kapatılmış Dayanışma Sendikası'nın üst düzey yöneticileri bu kapsam dışında

\footnotetext{
161 “Jaruzelski: 'Gdansk Anlaşmasının Ruhuna Sadığız”, Milliyet, 05 Temmuz 1983.

162 "Walesa: Bu Yasalar Yerine Sıkıyönetimi Tercih ederim", Milliyet, 19 Temmuz 1983.

163 "Polonya'da Sıkıyönetim Kalkıyor", Tercüman, 22 Temmuz 1983.

164 "Jaruzelski: 'Sıkıyönetim Kalktı Diye Anarşi Geri Gelecek Sanmayın”", Milliyet, 23 Temmuz 1983.

165 "Polonya'da Muhalefete Yine İzin Yok", Cumhuriyet, 23 Temmuz 1983.

166 "Polonya'da Sıkıyönetim Kalkıyor", Tercüman, 22 Temmuz 1983.

167 "Jaruzelski: 'Sıkıyönetim Kalktı Diye Anarşi Geri Gelecek Sanmayın”,, Milliyet, 23 Temmuz 1983.

168 "Polonya'da Siyasal Tutukluların Serbest Bırakılmasına Başlandı", Cumhuriyet, 24 Temmuz 1983.
}

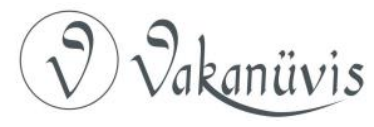


bırakılmıştır. ${ }^{169}$ Polonya halkı ise suskun kalmıştır. Bu suskunlukta yeni yasaların getirdiği "tedirginliğin" ve askerî yönetimin eskisinden daha çok yetkiye sahip olmasına inanılmasının etkili olduğu düşünülmüştür. ${ }^{170}$

Polonya'da olayların başlaması ve sıkıyönetim ilan edilmesiyle birlikte en çok tartışılan konular arasında Sovyetler Birliği'nin Polonya'ya askeri bir müdahalede bulunup bulunmayacağı yer almıştır. Polonya'da muhalefet artmaya başladığında ve Dayanışma Sendikası kurulduğunda Sovyetler Birliği'nin ekonomisi gerilemekteydi. 1979 yılında Sovyetler Birliği'nin Afganistan'ı işgal etmiş olması ve bu nedenle Batı'nın uyguladığı yaptırımlar Sovyetler Birliği'nin ekonomisini zora sokmuştu. Artan ekonomik sıkıntılar ve tıkanıklıklar nedeniyle Sovyetler Birliği'nin Batı ile her zamankinden daha fazla detanta ihtiyacı olmuştur. Aslında Sovyetler Birliği liderleri ilk başta Brejnev Doktrini'ne ${ }^{171}$ bağlı kalmak ve Polonya'da komünizmin çökmesine hiçbir şekilde izin vermeme niyeti taşımaktaydılar. Ancak Polonya'ya yapılacak askeri bir müdahalenin şiddetli bir direnişle karşılaşabileceği, Doğu-Batı detantını sona erdirebileceği ve daha sert ekonomik yaptırımlar getirebileceği göz ardı edilememiştir. Zira ABD, "Dayanışma" yanlısı bir uluslararası tanıtım kampanyası başlatmış ve Polonya işgalinin ciddi sonuçlar doğuracağı konusunda Sovyetler Birliği'ni sürekli uyarmıştır. Sovyetler Birliği bir müdahalede bulunmadığı sürece Batı tarafından cezalandırılmayacağı varsayımıyla işgal düşüncesi yerine Polonya yönetimine sıkıyönetim uygulanması konusunda baskı yapmıştır. Sovyetler Birliği liderleri "Polonyalı dostlarımızın kendi başlarına hareket etmelerini sağlamak için gerekli tüm önlemlerin alınması gerektiği" politikasına geçiş yaparak General Jaruzelski'yi sıkıyönetim ilan etmeye ve yönetimi almaya zorlamıştır. ${ }^{172}$

\footnotetext{
169 "Polonya'da Siyasal Tutukluların Serbest Bırakılmasına Başlandı", Cumhuriyet, 24 Temmuz 1983.

170 “Polonyalı’nın Ağzını Bıçak Açmıyor”, Tercüman, 24 Temmuz 1983.

171 Brejnev Doktrini, Leonid Brejnev tarafından 13 Kasım 1968 tarihinde Polonya Birleşik İşçi Partisi'nin Beşinci Kongresi'nde yaptığı açıklamaya dayanmaktadır. Brejnev, "sosyalizme düşman güçler herhangi bir sosyalist ülkeyi kapitalizme yönlendirmeye çalışırlarsa, bu [durum] yalnızca o ülkenin değil tüm sosyalist ülkelerin ortak sorunu ve kaygı sebebi olur" ifadesiyle reformlara girişen sosyalist ülkelere müdahalede bulunacaklarını ortaya koymuştur. Bkz. Karadeli, a.g.m., s. 251.

172“The Soviet Decision Not to Invade Poland, 1981" p. 140-142.
}

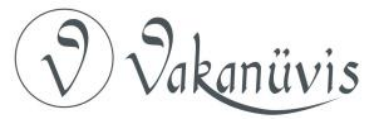


Soğuk Savaş dönemi ABD ile Sovyetler Birliği arasında her anlamda yarışın olduğu bir dönemdi. Ancak Sovyetler Birliği'nin ABD'nin sahip olduğu sermaye birikimi ve sanayisine karşı yarışı sürdürmesi zor olmuştur. ${ }^{173}$

13 Aralık 1981-22 Temmuz 1983 arasında yürürlükte kalan sıkıyönetim kısa vadede işe yaramıştır. Bu dönemde komünizme karşı muhalefetin faaliyetleri kırılmaya çalışılmıştır. Ancak ülkede ekonomik, siyasi ve toplumsal istikrar sağlanamamıştır. 1980'lerin sonunda "Dayanışma" yeniden ortaya çıkmıştır. ${ }^{174}$ "Dayanışma" ile hükümet arasında 1989 yılında "Yuvarlak Masa" görüşmeleri yapılmıştır. ${ }^{175}$ "Dayanışma" hareketinin en önemli başarısı 1989 seçimleri olarak görülmektedir. 1981-1983 arasında uygulanan sıkıyönetim döneminden sonra "Dayanışma" hareketi bastırılamamıştır. 4 Haziran 1989 'da seçimler yapılmış ve "Dayanışma" Senato'daki yüz sandalyenin doksan dokuzunu kazanmıştır. Yalta Konferansı'ndan bu yana Doğu Avrupa'da komünist olmayan ilk hükümet Polonya'da kurulmuştur. Lech Walesa ise 1990 yılında Polonya Cumhuriyeti'nin cumhurbaşkanı seçilmiştir. ${ }^{176}$ Polonya 1999 yılında NATO üyesi, 2004 yılında da Avrupa Birliği üyesi olmuştur. ${ }^{177}$

Genel olarak değerlendirildiğinde "Dayanışma" Avrupa'da komünizmi ve ardından Sovyetler Birliği'ni yok eden bir "deprem" olarak görülebilmektedir. ${ }^{178}$ "Dayanışma" nın 1989 yılında siyasi dönüşüm üzerinde güçlü bir etkisi vardır. ${ }^{179}$ Polonya Doğu Avrupa'da özgürlüğün sağlanmasında mihenk taşı olmuştur. ${ }^{180}$ Dayanışma Sendikası hareketinin yanı sıra 1985 yılında Sovyetler Birliği'nde Mihail Garbaçov'un iktidara gelmesiyle birlikte başlayan düzen değişimi

\footnotetext{
173 Sina Akşin, Kısa 20. Yüzyıl Tarihi, 4. Basım, Türkiye İş Bankası Kültür Yayınları, İstanbul 2017, s. 453.

174"The Soviet Decision Not to Invade Poland, 1981." p. 145, 149.

${ }^{175}$ Armaoğlu, a.g.e., s. 815.

${ }^{176}$ Kubow, a.g.m., p. 13, 14.

177 Kemal Beydilli, "Polonya: Tarih", TDV İslam Ansiklopedisi, Cilt 34, İstanbul, 2007, s. 316.

178"The Soviet Decision Not to Invade Poland, 1981" p. 145, 149.

179Janina Petelczyc, "Poland." Solidarity as a Public Virtue?:Lawand Public Policies in the European Union, edited by Veronica Federicoand Christian Lahusen, 1st ed., Nomos Verlagsgesellschaft MbH, Baden-Baden, Germany, (2018), p. 139.

180 Roberts, a.g.e., s. 741.
}

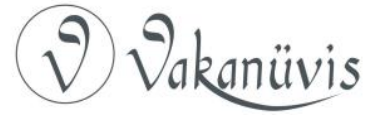


Sovyet güdümünde olan diğer ülkeleri de etkilemiştir. Bu değişimle 1989-1991 yılları arasında Polonya'dan sonra Macaristan, Çekoslovakya, Bulgaristan, Doğu Almanya, Arnavutluk ve Moğolistan'da da komünist rejim son bulmuş ve 1991 yılında Sovyetler Birliği dağılmıştır. ${ }^{181}$

\section{Sonuç}

Polonya jeopolitik ve stratejik konumu nedeniyle tarih boyunca büyük önem taşımış ve işgallere maruz kalmıştır. Birinci Dünya Savaşı'ndan sonra özgürlüğüne kavuşan Polonya, İkinci Dünya Savaşı'ndan sonra Sovyetler Birliği hegemonyasında kalarak Doğu Bloku üyesi olmuştur. Ancak Polonya'da iş̧̧iler başta olmak üzere halk dikte edilen komünist rejim altında istedikleri yaşam standartlarını elde edememiştir. Hak ettikleri karşılığı alamayan işçiler yönetime karşı harekete geçmiş ve Bağımsız Dayanışma Sendikası altında örgütlenmişlerdir. Olaylar Polonya'nın iç meselesi gibi başlasa da Doğu ve Batı Blokları arasında siyasi savaşa dönüşmüştür.

Türk basını olayları yakından takip ederek gelişmeleri Doğu ve Batı Blokları ekseninde de ele almıştır. Hatta Polonya darbesi ele alınırken Polonya'daki yönetimden ziyade $A B D$ ve Sovyetler Birliği'nin yaklaşımları daha ön planda olmuştur. Çalışmamızda kullandığımız gazetelere baktığımızda basının Polonya'daki Sendika hareketini desteklediği görülmüştür. Öyle ki Milliyet gazetesi Lech Walesa'yı “Polonya'nın bağımsızlık sembolü ve Doğu Bloku işçilerinin 'onur lideri'” olarak tanımlamıştır. Basındaki hâkim görüş sosyalist bir ülke olan Polonya'da Sovyet güdümündeki komünist sistemin iflas ettiği yönünde olmuştur. Yapılan bu değerlendirmeler görülmüştür ki oldukça doğrudur. Zira Sovyetler Birliği hegemonyasına karşı başlatılan "Dayanışma" hareketi Doğu Bloku'nun ve Sovyetler Birliği'nin dağılmasıyla sonuçlanmıştır.

${ }^{181}$ Uçarol, a.g.e.,ss. 1113, 1114.

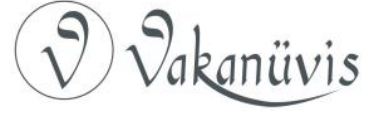




\title{
Kaynakça
}

\author{
Gazeteler \\ Cumhuriyet gazetesi (1981-1983) \\ Milliyet (1981-1983) \\ Tercüman (1981-1983)
}

\section{Kitap ve Makaleler}

Akkor, Mahmut, “II. Dünya Savaşı'nın Sonu ve Truman Doktrini'nin Ortaya Çıkışı", VAKANÜViS-Uluslararası Tarih Araştırmaları Dergisi, 2/2, (2017), s. 117.

Akşin, Sina, Kısa 20. Yüzyıl Tarihi, 4. Basım, İstanbul 2017.

Aktay, Yasin, "Türkiye'de İslam ve Sol veya İslamcılar ve Solcular", Modern Türkiye'de Siyasi Düşünce: Dönemler ve Zihniyetler, Ed. Tanıl Bora ve Murat Gültekingil, Cilt 9, İstanbul, 2009, s. 758-784.

Armaoğlu, Fahir, 20. Yüzyıl Siyasi Tarihi (1914-1995), 23. Basım, İstanbul 2017.

Asyalı, Abdulaziz, Doğu Avrupa Ülkelerinin Sosyalizmden Kopuşu ve Demokratikleşme Süreci: Polonya Örneği, Basılmamış Yüksek Lisans Tezi, Mardin 2019.

Bayır, Özgün Erler, Soğuk Savaş Sonrası Atlantikçilik-Avrupacılık ikileminde Polonya Dış Politikası, Basılmamış Doktora Tezi, İstanbul 2011.

Benlisoy, Foti, "Türk Milliyetçiliğinde Katedilmemiş Bir Yol: 'Hıristiyan Türkler'", Modern Türkiye'de Siyasi Düşünce: Milliyetçilik, Ed. Tanıl Bora ve Murat Gültekingil, Cilt 4, 3. Basım, İstanbul 2008, s. 927-933.

Civelek, Jale, "Helsinki Son Senedi, Paris Şartı ve AGiT", Marmara Üniversitesi Avrupa Topluluğu Enstitüsü Avrupa Araştırmaları Dergisi, 14/1 (2006), s. 1-23.

Çınar, Yusuf, "Modernleşme ve Bağımlılık Teorisi Ekseninde Marshall Yardımı ve Türkiye", MCBÜ Sosyal Bilimler Dergisi, 16/2, (2018), s. 325-350.

Gönlübol, Mehmet ve Haluk Ülman, "ikinci Dünya Savaşından Sonra Türk Dış Politikası (1945-1965): Genel Durum", Olaylarla Türk Dış Politikası (19191995), 9. Basım, Ankara 1996.

Karadeli, Cem, "Stalin ve Kruşçov Dönemlerinde Doğu Avrupa'da Sovyetler ve Krizler", Ufuk Üniversitesi Sosyal Bilimler Enstitüsü Dergisi, 8/15, (2019), s. 239-253.

Kemal Beydilli, "Polonya”, TDV İslam Ansiklopedisi, Cilt 34, İstanbul 2007, s. 309-317.

Kubow, Magdalena, "TheSolidarityMovement in Poland: ItsHistoryandMeaning in Collective Memory." ThePolishReview, 58/2 (2013), p. 3-14.

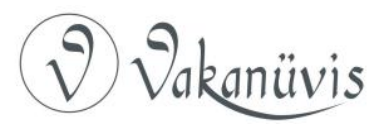


Kulczycki, John J., "TheBeginnings Of TheSolidarityMovement in Poznan, 1980-1981", ThePolishReview, Vol. 27, No. 3/4 (1982), p. 154-169.

McNeill, William H., Dünya Tarihi, Çev. Alaeddin Şenel, 6. Basım, Ankara 2002.

Petelczyc, Janina, "Poland." Solidarity as a PublicVirtue?:LawandPublicPolicies in theEuropeanUnion, editedbyVeronicaFedericoandChristianLahusen, 1st ed., NomosVerlagsgesellschaftMbH, Baden-Baden, Germany, (2018), p.129-146.

Roberts, J.M., Avrupa Tarihi, çev. Fethi Aytuna, İstanbul 2015.

Sander, Oral, Siyasi Tarih 1918-1994, 5. Basım, Ankara, 1996.

TheSovietDecision Not tolnvade Poland, 1981." Blinders, Blunders, andWars: WhatAmericaandChina Can Learn, by David C. Gompert et al., RAND Corporation, 2014, p. 139-150.

Uçarol, Rifat, Siyasi Tarih (1789-2014), 10. Basım, İstanbul 2015.

Zaremba, Marcin, "The 'WarSyndrome': World War II andPolishSociety." SeekingPeace in the Wake of War: Europe, 1943-1947, editedby StefanLudwig Hoffmann et al., Amsterdam UniversityPress, Amsterdam, (2015), p. 27-62.

https://www.president.pl/en/president/polish-presidents/lech-walesa/, (17.03.2021). 


\section{EKLER}

Ek 1:Darbenin ardından Polonya ve çevresinde bulunan Sovyet Birliği'ne ait askeri birlikler. ${ }^{182}$

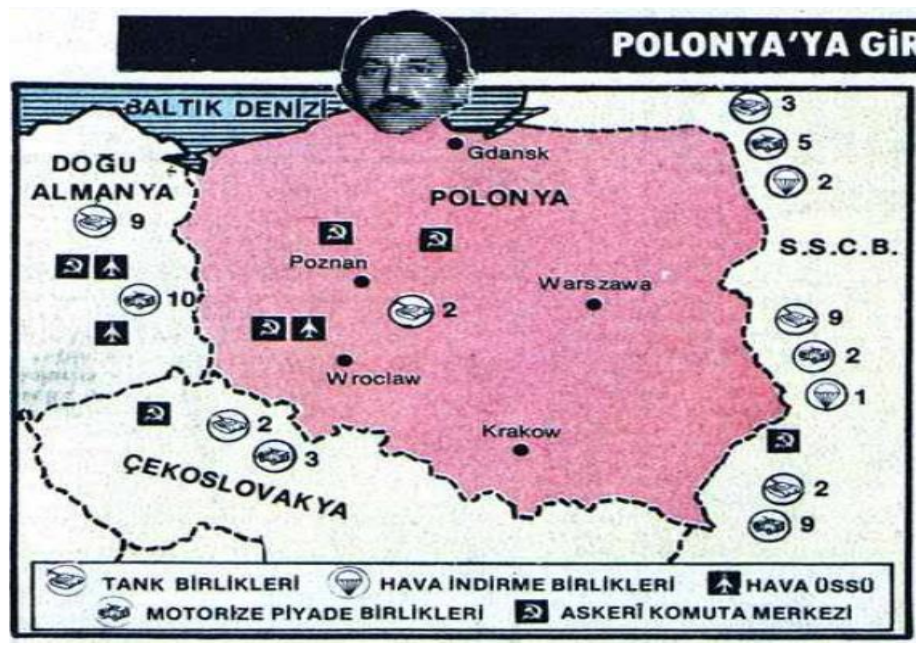

Ek 2: Milliyet gazetesinin 5 Ocak 1982 tarihli sayısında Polonya'daki durumuanlatan fikralar.

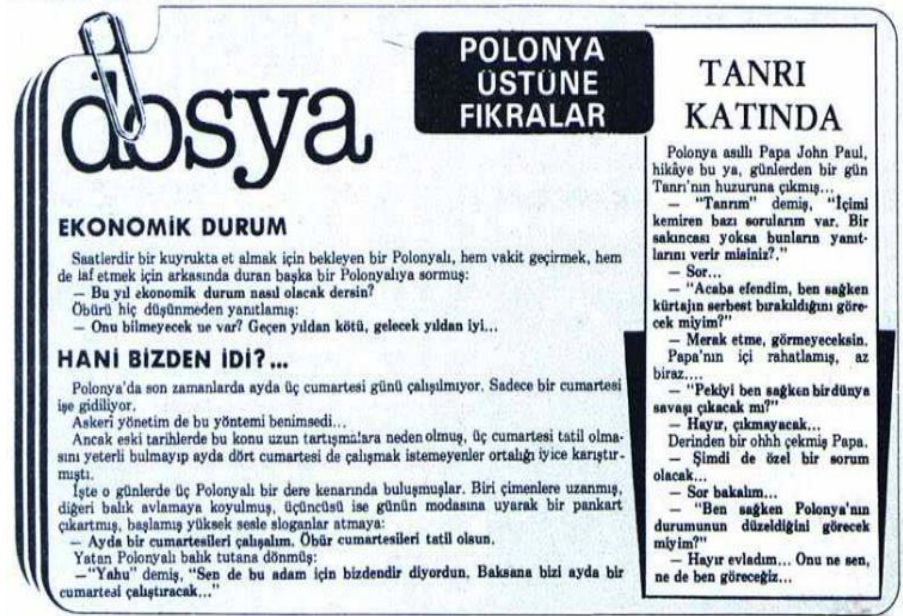

182Milliyet, 14 Aralık 1981.

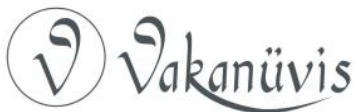

